\title{
Requirement Analysis of Computing Curriculum Standard J07 and Japan Information Technology Engineers Examination Using ICT Common Body of Knowledge
}

\author{
Tetsuro Kakeshita $^{1, \text { a) }}$ Mika Ohtsuki ${ }^{1, b)}$ \\ Received: March 18, 2013, Accepted: October 9, 2013
}

\begin{abstract}
Information Processing Society of Japan (IPSJ) has announced the Computing Curriculum Standard J07 which is compatible with the Computing Curricula 2005 (CC2005) Series proposed in the United States. Both J07 and CC2005 are composed of five major domains, CS, CE, SE, IS and IT, each of which is developed by a different community so that the relationship among these domains is not clear. In this paper, we analyze each body of knowledge (BOK) of the domains and map them into the ICT common body of knowledge (ICTBOK) which we have proposed in our previous paper. We also analyze Japan Information Technology Engineers Examination (JITEE) whose syllabus is published for each of 12 examination categories provided by the Japanese government. We estimate the degree of importance and the requirement level in terms of the 155 ICTBOK areas for each J07 domain and JITEE examination category by utilizing the mapping. Moreover we estimate the similarity and the difference among them. As a result, the relationship among J07 domains and JITEE examination categories is clarified.
\end{abstract}

Keywords: requirement analysis, J07, Japan Information Technology Engineers Examination, ICT education, ICT human resource development

\section{Introduction}

Information Processing Society of Japan (IPSJ) announced the Computing Curriculum Standard J07 [1] as a guideline for college level ICT education. J07 is essentially compatible with the Computing Curricula 2005 (CC2005) [2] developed by ACM, IEEE Computer Society (IEEE-CS) and AIS. Considering the diversity of the computing disciplines, the following five major domains are defined both in $\mathrm{J} 07$ and $\mathrm{CC} 2005$.

- CS: Computer Science

- CE: Computer Engineering

- SE: Software Engineering

- IS: Information Systems

- IT: Information Technology

Each domain of J07 and CC2005 is developed by a different community for historical reasons so that the body of knowledge (BOK) of each domain is described using a different terminology. As a result, the relationship among these domains is not concrete and clear not only for the society including the industry and the government but also for professors and students of ICT departments. This situation is not desirable for many stakeholders of the computing curriculum.

Industry and the Japanese ministry of industry both realize that ICT (Information and Communication Technology) is necessary for global competition. The Japanese government and the local

\footnotetext{
Department of Information Science, Saga University, Saga 840-8502 Japan

a) kake@is.saga-u.ac.jp

b) mika@is.saga-u.ac.jp
}

governments want to increase their business efficiency by developing and operating a digital government. A large number of high level ICT professionals are required to achieve these goals.

IPA (Information Technology Promotion Agency) is a governmental organization and supplies Japan Information Technology Engineers Examination (JITEE) composed of 12 examination categories to visualize entry and middle level ICT professionals. JITEE is a well-known ICT qualification in Japan and over 600,000 examinees take the examination each year.

In this paper, we analyze the BOKs of the five J07 domains and map them into the ICT common body of knowledge (ICTBOK) which we have proposed in our previous paper [3]. ICTBOK is composed of 7 categories, 23 fields and 155 areas; and covers a wide range of knowledge and skill required for ICT professionals. We also analyze JITEE examination categories by making a correspondence between the syllabus of each category and ICTBOK. Thus a clear and concrete analysis becomes possible in order to clarify the relationship among J07 domains and JITEE examination categories.

As of June 2013, there is no ICT examination which directly corresponds to a computing curriculum standard such as CC2005 and J07. IEEE-CS is running CSDP (Certified Software Development Professional) examination based on SWEBOK (Software Engineering Body of Knowledge). J07-CS refers a small subset of SWEBOK since J07-CS is developed for college graduates while SWEBOK is developed for software engineer having 4 years of working experience. IEEE-CS announced on June 2012 that they are going to use SFIA [4] to define the skill of ICT professional and ICT student. The corresponding activity is 
just starting. In this sense, this paper treats a challenging research domain.

The detail of ICTBOK is described in Section 2. The structures of J07 and JITEE are introduced in Sections 3 and 4 respectively. We shall overview the analysis plan in Section 5. In Section 6, we map BOK of each J07 domain into ICTBOK. Then we estimate the degree of importance of the 23 fields of ICTBOK for each J07 domain. The requirement level of each ICTBOK area is also estimated for each domain. We also analyze each JITEE examination category in Section 7 by making the correspondence between ICTBOK and the syllabus of the examination category. We shall compare the analysis results in Section 8.

\section{ICT Common Body of Knowledge}

ICT common body of knowledge (ICTBOK) is developed to uniformly represent the knowledge and skill of ICT professionals belonging to various job categories and levels [3]. ICTBOK also provides a common vocabulary to define various activities of ICT education such as the requirement and the achievement of an ICT education program. ICTBOK is composed of 7 categories, 23 fields and 155 areas. The readers can find the entire ICTBOK in Appendix A.1.

IPA announces three types of skill standards for ICT professionals [5]. They are

(1) ITSS (skill standards for IT professionals) for people working for IT services industry,

(2) ETSS (embedded technology skill standards) for embedded software engineers, and

(3) UISS (user's information system skill standards) for information system users.

We have analyzed the three skill standards and have defined ICTBOK. ICTBOK also covers the teaching domain of college level ICT education by analyzing and integrating the J07 curriculum standard.

Table 1 represents categories and fields of ICTBOK. Each field in Table 1 is associated by the abbreviation (such as FND) and the number of areas corresponding to the field. In addition to the BOK explained above, ICTBOK also contains the category "competences" expected as a society member. The fields of the competences are developed by the ministry of economy, trade and industry of the Japanese government. The "others" category is defined so that users can add areas if there are some missing areas in ICTBOK.

We shall call the Business and Competences categories as nonICT categories among the seven categories of ICTBOK, while the remaining five categories as ICT categories.

\section{Computing Curriculum Standard J07}

J07 is composed of six domains, CS, CE, SE, IS, IT and GE [1]. Here GE is a curriculum standard for general ICT education for non-ICT students and is excluded from the analysis of this paper. The other five domains correspond to CC2005 domains with some modifications to adopt the teaching environment in Japan. A conceptual relationship of the domains is illustrated in Fig. 1.

The curriculum of a Japanese university is typically composed of three parts: one-year general education, two-year technical education for a specific major domain, and a one-year graduation research project. J07-GE is designed for non-ICT students as a part of their general education. Other J07 domains are designed for ICT students as a part of their technical education. Since the ICT discipline is rapidly growing and J07 is proposed as a guideline for ICT curriculum development, IPSJ does not intend to strictly "define" the ICT curriculum. Instead, J07 defines core units for one-year technical education in ICT as a body of knowledge (BOK) for each domain. Although ICT departments are expected to choose one of the five domains, they can freely design the remaining three-year part of their curriculum.

Among the domains of J07, CS, CE and IT have the same structure. For example, the BOK of the CS domain (J07-CSBOK) is composed of 15 knowledge areas and 138 units. The minimum core coverage time, topics and learning objectives are defined for each unit. If the minimum core coverage time of a unit is greater than 0 , the unit is called a core unit. The expected outcomes of

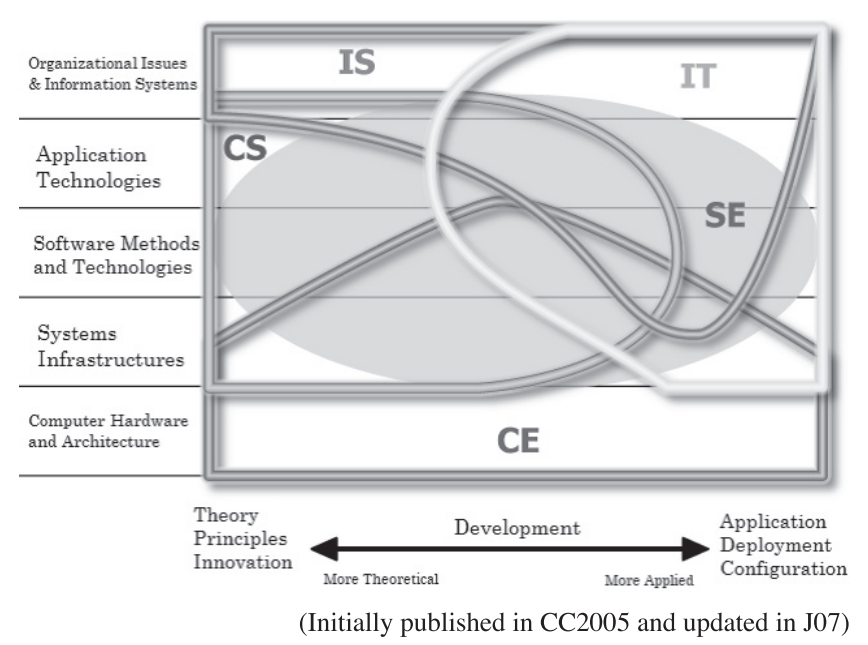

Fig. 1 Conceptual relationship of J07 domains.

Table 1 Categories and fields of ICTBOK.

\begin{tabular}{l|l}
\hline \hline \multicolumn{1}{c|}{ Category } & \multicolumn{1}{c}{ Field } \\
\hline $\begin{array}{l}\text { Foundations of } \\
\text { Computer Sci- } \\
\text { ence }\end{array}$ & $\begin{array}{l}\text { Fundamental Theory (FND, 7) / Mathematics, Ap- } \\
\text { plied Mathematics (MATH, 5) / Computer Architec- } \\
\text { ture (ARCH, 9) / Hardware (HW, 7) / Operating Sys- } \\
\text { tem (OS, 5) }\end{array}$ \\
\hline $\begin{array}{l}\text { Media, Human } \\
\text { Computer }\end{array}$ & $\begin{array}{l}\text { Multimedia Data Processing (MMDP, 8) / Human In- } \\
\text { terface (HUI, 3) / Usability (2) / Intelligent System } \\
\text { Interaction }\end{array}$ \\
\hline $\begin{array}{l}\text { Network and 6) } \\
\text { Security }\end{array}$ & $\begin{array}{l}\text { Telecommunication System (Telecomm, 9) / Com- } \\
\text { puter Network (NET, 6) / Web Technology (WEB, 8) / } \\
\text { Security (6) }\end{array}$ \\
\hline
\end{tabular}

\begin{tabular}{l|l}
\hline \hline \multicolumn{1}{c|}{ Category } & \multicolumn{1}{c}{ Field } \\
\hline $\begin{array}{l}\text { Software } \\
\text { Development }\end{array}$ & $\begin{array}{l}\text { Database (DB, 6) / Algorithm and Data Structure } \\
\text { (ALGO, 5) / Computer Programming (PRG, 5) / Soft- } \\
\text { ware Engineering (SWE, 11) }\end{array}$ \\
\hline $\begin{array}{l}\text { Information } \\
\text { System }\end{array}$ & $\begin{array}{l}\text { Project Management (PM, 6) / System Operation and } \\
\text { Evaluation (OPR, 8) }\end{array}$ \\
\hline Business & $\begin{array}{l}\text { Business and Administration (Business, 8) / Commu- } \\
\text { nications (COMM, 5) / Society and Ethics (SOC, 4) }\end{array}$ \\
\hline Competency & Behavior (3)/ Thinking (3) / Teamwork (6) \\
\hline Others & $\begin{array}{l}\text { Additional fields or areas can be defined by users, if } \\
\text { necessary. }\end{array}$ \\
\hline
\end{tabular}


Table 2 Levels and examination categories of JITEE.

\begin{tabular}{|c|c|c|c|}
\hline \multicolumn{2}{|c|}{ Common Career / Skill Framework } & Expected Examinee & Categories of Information Technology Engineers Examination \\
\hline Level 4 & $\begin{array}{l}\text { Advance Level Knowledge } \\
\text { and Skills }\end{array}$ & $\begin{array}{l}\text { IT Professionals who can } \\
\text { lead a project }\end{array}$ & \begin{tabular}{ll} 
& \multicolumn{1}{c}{ Advanced Level Examination } \\
- Information Technology Strategist Examination (ST) \\
- System Architect Examination (SA) \\
- Project Manager Examination (PM) \\
- Network Specialist Examination (NW) \\
- Database Specialist Examination (DB) \\
- Embedded Systems Specialist Examination (ES) \\
- Information Security Specialist Examination (SC) \\
- Information Technology Service Manager Examination (SM) \\
- System Auditor Examination (AU)
\end{tabular} \\
\hline Level 3 & $\begin{array}{l}\text { Applied Knowledge and } \\
\text { Skills }\end{array}$ & $\begin{array}{l}\text { Master course graduates } \\
\text { majored in IT }\end{array}$ & Applied Information Technology Engineer Examination (AP) \\
\hline Level 2 & $\begin{array}{l}\text { Fundamental Knowledge } \\
\text { and Skills }\end{array}$ & $\begin{array}{l}\text { College graduates willing } \\
\text { to be IT engineers }\end{array}$ & Fundamental Information Technology Engineer Examination (FE) \\
\hline Level 1 & $\begin{array}{l}\text { Fundamental Knowledge } \\
\text { Required of All Workers }\end{array}$ & $\begin{array}{l}\text { All working member of the } \\
\text { society }\end{array}$ & Information Technology Passport Examination (IP) \\
\hline
\end{tabular}

the student are defined as learning objectives. The topics describe the teaching topics of the unit.

The structures of SE and IS are different from the above.

J07-SEBOK is composed of 17 knowledge areas and 297 units. J07-SE is based on SE2004 [2] except that core time is not defined for each unit. Instead, each unit is assigned to some course whose syllabus contains the weekly plan. The weekly plan also contains the learning objectives for the corresponding unit.

The main components of J07-IS are the learning units (LU). J07-IS is based on IS2002 [2] developed by AIS. 209 LUs are defined in J07-IS. Among them 108 are the core LUs. Each LU is composed of LU\#, level, teaching and learning objectives. The level of a LU is between 0 and 5; 0 stands for "does not know," 1 for recognize, 2 for explain, 3 for utilize, 4 for apply, 5 for proficient.

\section{Japan Information Technology Engineers Examination}

The Japan Information Technology Engineers Examination (JITEE) is a set of examinations provided by the Japanese government [6]. The government has announced Common Career/Skill Framework (CCSF) as a framework to make correspondence among three skill standards for IT professionals and JITEE. JITEE covers various levels of IT knowledge and skill from IT literacy (level 1) to the advanced level for IT engineers (level 4) as illustrated in Table 2. As also illustrated in the table, these levels correspond to the expected levels for college students of various backgrounds. J07 corresponds to Level 2 in Table 2, since J07 is designed for a college level ICT education.

JITEE is composed of 12 examination categories. The level 1 examination (IP) is composed of 100 multiple-choice questions to evaluate the examinee's knowledge. The level 2 examination (FE) is also composed of multiple-choice questions. FE examination contains morning and afternoon exams to evaluate the examinee's knowledge and skill levels respectively. The level 3 and 4 examinations (AP and above) also contain morning and afternoon exams to evaluate knowledge and skill. The morning exam is composed of multiple-choice questions, while the afternoon exam is mainly composed of short answer questions to which applicants must write short text. The remaining questions of the afternoon exam requires longer essay describing the examinee's
Table 3 Description of objectives for JITEE.

\begin{tabular}{l|l}
\hline \hline \multicolumn{1}{c|}{ Description } & \multicolumn{1}{c}{ Definition } \\
\hline Understand & Need to learn as a knowledge \\
\hline $\begin{array}{l}\text { Apply with as- } \\
\text { sistance }\end{array}$ & $\begin{array}{l}\text { Apply the knowledge and partly solve a problem } \\
\text { under the guidance of the leader }\end{array}$ \\
\hline $\begin{array}{l}\text { Understand } \\
\text { and apply }\end{array}$ & $\begin{array}{l}\text { Understand the leader's policy and apply the } \\
\text { knowledge to solve a problem }\end{array}$ \\
\hline $\begin{array}{l}\text { Understand } \\
\text { and utilize }\end{array}$ & $\begin{array}{l}\text { Combine a related set of knowledge and apply } \\
\text { them to solve a problem }\end{array}$ \\
\hline
\end{tabular}

opinion or experience under the specified situation. Thus a 5-year working experience as an IT engineer is typically required to pass the level 4 examinations.

The syllabus of each examination category is a set of topics. Each topic is classified using a two-level hierarchy and is composed of an objective and a content. The objective briefly explains the scope and the depth of the topic which an examinee is expected to achieve. The scope and the depth are described in a standard form as summarized in Table 3. The content describes the detailed topics along with examples of technical terms and an application of knowledge in a concrete manner.

\section{Common Analysis Plan of J07 and JITEE}

ICTBOK has a three-level hierarchical structure composed of categories, fields and areas. We shall assign the requirement level of each area through the analysis. In order to do this, we define requirement levels 0 to 5 as shown in Table 4. The reader should note that the definition of the levels is slightly different from the levels ${ }^{* 1}$ defined in Table 2 in order to describe the level more precisely especially for college level education. Basically, the levels are defined according to the Bloom's taxonomy. The difference between levels 0 and 1 for skill is that some education or training is required to achieve level 1 . Level 2 is the level to explain the knowledge area or to execute the knowledge with detailed instructions. Level 3 of the skill is the level to execute the area with simplified instructions. Typically extensive training at a laboratory is required to achi eve level 3 while learning or exercise at a 15 -week course is required to achieve level 2. Education to earn a master degree is usually expected to achieve level 4 . A student or ICT professional is required to combine related knowledge to achieve knowledge level 4 . The level also implies that the student

\footnotetext{
*1 Hereafter, we describe the levels defined in Table 2 as CCSF levels.
} 
Table 4 Achievement and requirement levels.

\begin{tabular}{c|l|l}
\hline \hline Level & \multicolumn{1}{|c|}{ Knowledge } & \multicolumn{1}{c}{ Skill } \\
\hline 0 & Do not know & Cannot execute \\
\hline 1 & Understand or know & $\begin{array}{l}\text { Execute with detailed in- } \\
\text { structions }\end{array}$ \\
\hline 2 & Explain & $\begin{array}{l}\text { Execute with simple instruc- } \\
\text { tions }\end{array}$ \\
\hline 4 & $\begin{array}{l}\text { Join a discussion using the the knowledge for } \\
\text { knowledge }\end{array}$ & Proficient in the skill \\
\hline 5 & \multicolumn{1}{|c}{ Unused } & Can teach others \\
\hline
\end{tabular}

Table 5 Examples of verbs to describe learning objectives.

\begin{tabular}{|c|c|}
\hline Knowledge & Skill \\
\hline $\begin{array}{l}\text { understand, explain, describe, } \\
\text { state, illustrate by example, } \\
\text { compare, differentiate, discuss }\end{array}$ & $\begin{array}{l}\text { compute, perform, use, solve, de- } \\
\text { velop, design, implement, test, de- } \\
\text { bug, create, apply, choose, analyze }\end{array}$ \\
\hline
\end{tabular}

or ICT professional can teach the knowledge to others so that we do not define knowledge level 5.

We also estimate the weight of each area representing the degree of importance of the area through the requirement analysis.

The analysis of J07 is carried out in order to estimate the requirement level and the weight of each ICTBOK area for each domain of J07.

Among the domains of J07, CS, CE and IT have the same structure. Thus we shall explain the common analysis plan for these three domains. The remaining two domains, SE and IS, will be discussed in Section 6.

Assuming the above BOK structure explained in Section 2, we first make the correspondence between the core units and the areas of ICTBOK. If a unit corresponds to a single area, the core coverage time of the unit is assigned to the area. In case that multiple areas correspond to a unit, the core time is proportionally distributed among the areas considering the learning objectives and topics of the unit.

When we have built the correspondence, the weight of each area is computed by the sum of the core times of the area. The weight of each category and field can be computed similarly.

The requirement level of each area is basically determined from the learning objectives of the corresponding core units. The learning objectives are described using various verbs summarized in Table 5. Knowledge and skill requirements can be evaluated by these verbs. However, the requirement level is set to zero, if the assigned core time is zero since the teaching of the area is not guaranteed. The requirement level is set to one if the assigned core time is an hour or less, since it is expected to be difficult to teach an area within an hour so that students can explain the area.

After estimating the requirement level and weight of each area, we summarize the analysis result by summing the weight for each field to overview the distribution of weight for 23 fields of ICTBOK. We also count the number of areas with a requirement level greater than 1 and the average requirement level among such areas. The information represents the overall profile of a J07 domain.

The analysis of JITEE is carried out essentially in the same process of J07 requirement analysis. However each syllabus does not contain the notion of core time so that we shall use the number of topics instead to estimate the weight of each ICTBOK area $* 2$. The knowledge and skill level of each area is estimated based on the assigned topics and the corresponding description of the objectives as explained in Table 3.

\section{Requirement Analysis of J07 Domains}

\subsection{Common Analysis Result}

Figure 2 illustrates the distributions of the importance levels (weights) of the fields of the J07 domains. The weights of the fields are normalized so that the sum of the weights is equal to $100 \%$ for each domain.

Table 6 represents the numbers of covered ICTBOK areas for each J07 domain and the average requirement level for knowledge and skill. This is useful to visualize the scope and the depth of each domain in a quantitative manner. No area has a requirement level 3 or more because level 3 is typically achieved by extensive training through a graduation research project which is outside of the scope of J07. Thus the average part of the requirements is represented by the number of level 2 areas.

The readers can find a list of ICTBOK areas for each J07 domain in Appendix A.2. The areas are sorted in the descending order of weight (importance level) and the estimated requirement levels are associated for knowledge and skill.

\subsection{Computer Science (CS)}

Analysis of J07-CS is carried out as explained in Section 5. The correspondence between ICTBOK areas and J07-CSBOK units has been reviewed for correctness by a J07-CS committee member. In Japan, the majority of ICT departments teach computer science, which focus on the theory and modeling issues. However, CS is not only a theoretical domain. CS also focuses on computer programming and software engineering as can be seen from Fig. 2. This may be contrary to the intuition for the readers. Such a quantitative analysis becomes possible using our approach.

The number of covered ICTBOK areas and the average requirement level are at the average among the five disciplines.

\subsection{Computer Engineering (CE)}

Analysis of J07-CE is carried out as described in Section 5. CE is the second largest community of ICT departments in Japan. J07-CE focuses on hardware, architecture and embedded software development. Compared with CE2004 [2], the software issue is more emphasized in J07-CE. This can be observed in Fig. 2 by the weights assigned to software engineering, computer programming, and database.

\subsection{Software Engineering (SE)}

Taking the structure of J07-SE, explained in Section 4, into consideration, we assign each week of the J07-SE courses to ICTBOK areas. The weight of the area is defined by the number of courses. For example, the weight of an area becomes 2/13 if two weeks of a 13-week course correspond to the area. The

\footnotetext{
*2 If a JITEE syllabus introduces the notion of weight or core time for each
} topic, a more precise requirement analysis will become possible. 

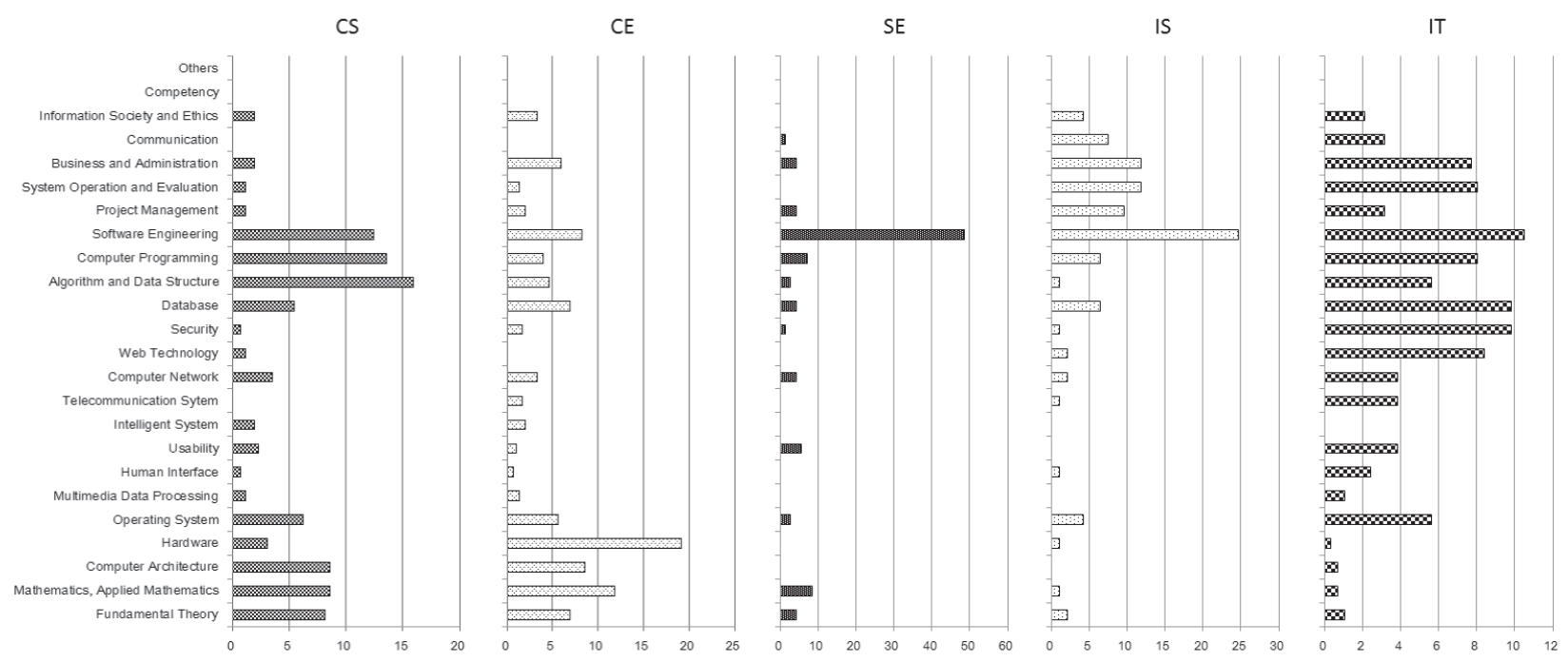

$(\%)$

Fig. 2 Importance level distribution of J07 domains.

Table 6 Number of corresponding ICTBOK areas and average requirement level of J07 domains.

\begin{tabular}{l|c|c|c|c|c|c|c|c|c|c}
\hline \hline & \multicolumn{9}{|c|}{ Knowledge } & \multicolumn{5}{c}{ Skill } \\
\cline { 2 - 12 } & CS & CE & SE & IS & IT & CS & CE & SE & IS & IT \\
\hline \# of ICTBOK areas & 50 & 61 & 40 & 73 & 69 & 27 & 22 & 20 & 22 & 69 \\
\hline Average requirement level & 1.86 & 1.82 & 1.55 & 1.32 & 1.84 & 1.89 & 1.73 & 1.45 & 2.09 & 1.41 \\
\hline
\end{tabular}

knowledge and skill requirement levels are estimated according to the following criteria.

- Knowledge and skill requirement levels are zero if the area has no weight.

- The knowledge requirement level is one if the weight of the area is less than or equal to $2 / 13$; two if the weight is more than $2 / 13$.

- The skill requirement level is computed in a similar way as in the case of a knowledge requirement level. The only difference is that the weight is defined by the number of exercises instead of lectures.

J07-SE strongly focuses on the software engineering field as illustrated in Fig. 2. This is because J07-SE intends to develop a highly skilled software developer. However the average skill requirement level (1.45) is at the lowest level among the five domains.

\subsection{Information Systems (IS)}

The analysis of J07-IS is carried out using the core LUs. We first assign every LU to an ICTBOK area. If there are more than one areas corresponding to an $\mathrm{LU}$, the number of $\mathrm{LU}$ is proportionally assigned to each area. The weight of each area is computed by the number of core LUs corresponding to the area.

Requirement levels are determined using the following rules.

- Knowledge and skill requirement levels are zero if there is no core LU corresponding to the area.

- The knowledge requirement level of an area is one if the levels of corresponding core LUs are either 0 or 1 , two if the level of a corresponding core LUs is 2 or above.

- The skill requirement level of an area is one if the levels of corresponding core LUs are 3, two if the level of a corresponding core LU is either 4 or 5.
Information systems focus on business administration, system operation and project management as well as software engineering. This is because that J07-IS ultimately aims at developing chief information officer (CIO). The average requirement knowledge level is the lowest among the five $\mathrm{J} 07$ domains. But the number of covered ICTBOK areas for a knowledge is the largest. This implies that J07-IS requires graduates to have a wide range of knowledge as a CIO candidate. Although the number of ICTBOK areas for a skill is at the lowest level, the skill requirement level is the highest.

\subsection{Information Technology (IT)}

Analysis of J07-IT is carried out as described in Section 5. J07IT is partly similar to J07-IS, but J07-IT focuses on developing a computer administrator. This can be observed from Fig. 2 by the weights assigned to the fields such as database, security and web technology. Compared with other J07 domains, the weight of each field is more widely distributed. The number of covered areas for a skill is the largest among the five domains. This implies that J07-IT requires practical knowledge and skill as computer administrators.

\section{Requirement Analysis of JITEE Examina- tion Categories}

Before analyzing JITEE examination categories, we asked for a review to a senior staff of IPA Skill Standard Center on correspondence between ICTBOK and JITEE syllabuses. Thus the succeeding analysis result can be considered valid.

Figure 3 illustrates the distributions of the importance levels (weights) of the fields of JITEE examination categories. The weights of the fields are normalized so that the sum of the weights is equal to $100 \%$ as in the case of J07 analysis. 

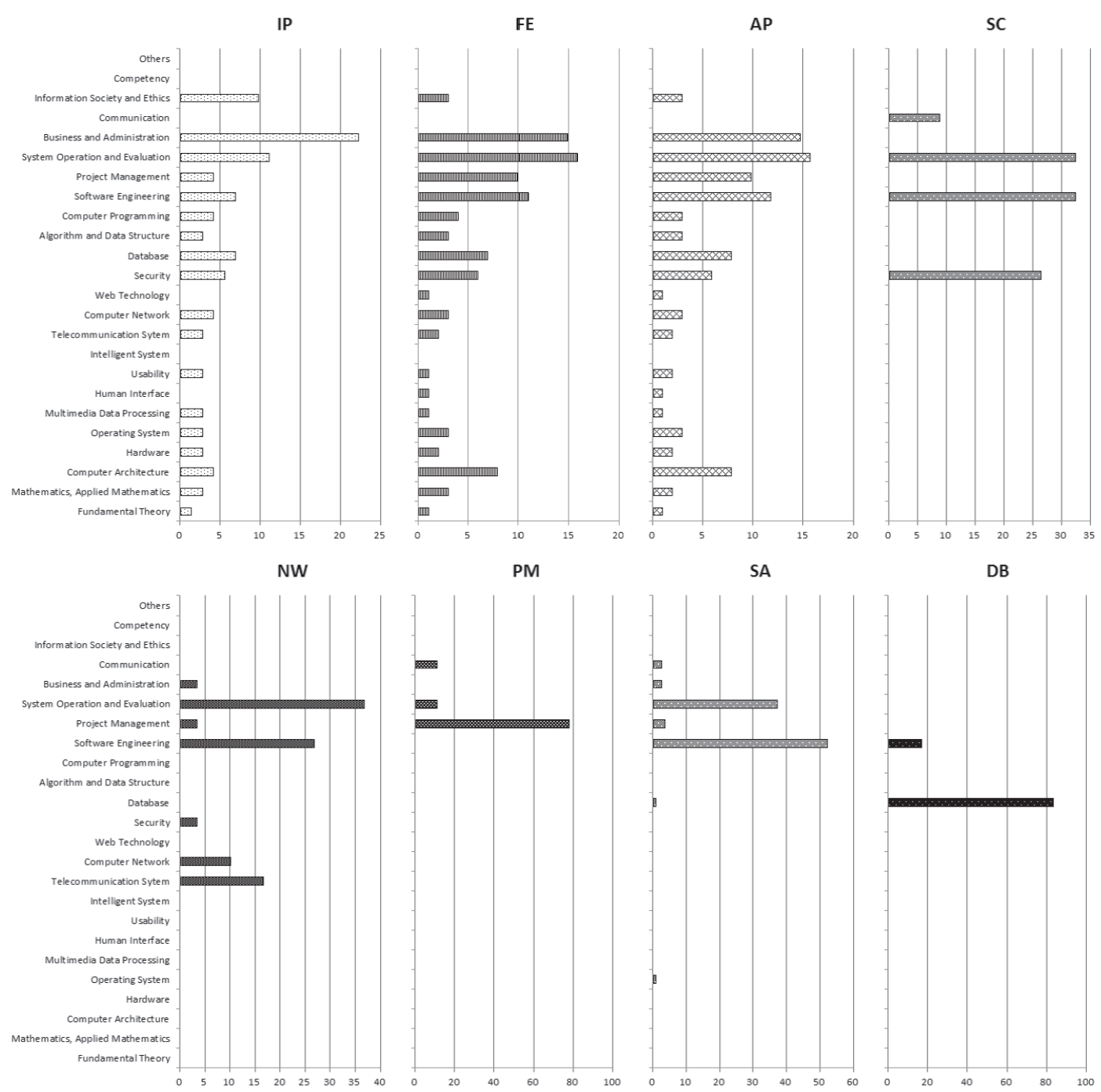

Fig. 3 Importance level distribution of JITEE examination categories.

Table 7 Number of corresponding ICTBOK areas and average requirement level of JITEE examination categories.

\begin{tabular}{l|c|c|c|c|c|c|c|c}
\hline \multicolumn{1}{|c|}{ Knowledge } \\
\hline \hline \# of ICTBOK areas & IP & FE & AP & SC & NW & PM & SA & DB \\
\hline Average requirement level & 1.04 & 82 & 94 & 10 & 12 & 10 & 21 & 4 \\
\hline
\end{tabular}

\begin{tabular}{l|c|c|c|c|c|c|c|c}
\hline \multicolumn{1}{|c|}{ Skill } \\
\hline \hline \# of ICTBOK areas & IP & FE & AP & SC & NW & PM & SA & DB \\
\hline Average requirement level & 2 & 59 & 94 & 10 & 12 & 10 & 21 & 4 \\
\hline
\end{tabular}

Table 7 represents the numbers of covered ICTBOK areas for each JITEE examination category and the average requirement levels for knowledge and skill.

We can find the followings by observing Fig. 3 and Table 7.

- IP, FE and AP require a wide range of areas, while advanced level examinations require specific areas. Examinees must have knowledge and skill required for AP in order to pass the advanced examination. In this sense, an advanced examination syllabus only describes the specific knowledge and skill of the examination categories.

- IP basically requires knowledge of level 1. It requires skill only at two areas. Thus we can correspond a combination of knowledge level 1 and skill level 0 to the level 1 of common career/skill framework (CCSF) defined in Table 2.

- In case of IP, more than $20 \%$ of the weight is assigned to nonICT fields (Business and administration). This is because that expected examinee of IP is a new working member of the society whose major may not be IT.

- Importance level distributions of FE and AP are similar. Both FE and AP focus more on IT fields than IP. The major difference between FE and AP is the average requirement levels of knowledge and skill. FE mainly requires level 2 
Table 8 Similarity among JITEE examination categories.

\begin{tabular}{c|c|c|c|c|c|c|c}
\hline \hline & IP & FE & AP & SC & NW & PM & SA \\
\hline FE & 0.8121 & 1 & & & & & \\
\hline AP & 0.8063 & 0.9953 & 1 & & & & \\
\hline SC & 0.2712 & 0.5519 & 0.5659 & 1 & & & \\
\hline NW & 0.3495 & 0.6182 & 0.6276 & 0.7669 & 1 & & \\
\hline PM & 0.0172 & 0.3119 & 0.3033 & 0.0108 & 0.0720 & 1 & \\
\hline SA & 0.3091 & 0.6103 & 0.6333 & 0.8268 & 0.8544 & 0.0644 & 1 \\
\hline DB & 0.1439 & 0.1875 & 0.2347 & 0.0300 & 0.0074 & -0.0659 & 0.1048 \\
\hline
\end{tabular}

Table 9 Similarity among J07 domains.

\begin{tabular}{c|c|c|c|c}
\hline \hline & CS & CE & SE & IS \\
\hline CE & 0.4515 & 1 & & \\
\hline SE & 0.4949 & 0.2533 & 1 & \\
\hline IS & 0.2515 & 0.1090 & 0.7726 & 1 \\
\hline IT & 0.2599 & -0.0868 & 0.4259 & 0.6087 \\
\hline
\end{tabular}

Table 10 Similarity between J07 domain and JITEE category.

\begin{tabular}{c|r|r|r|r|r}
\hline \hline & \multicolumn{1}{|c|}{ CS } & \multicolumn{1}{c|}{ CE } & \multicolumn{1}{c|}{ SE } & \multicolumn{1}{c}{ IS } & \multicolumn{1}{c}{ IT } \\
\hline IP & 0.0267 & 0.1694 & 0.1640 & 0.5325 & 0.4688 \\
\hline FE & 0.1389 & 0.1656 & 0.3361 & 0.7117 & 0.5679 \\
\hline AP & 0.1242 & 0.1546 & 0.3655 & 0.7284 & 0.5856 \\
\hline SC & 0.0400 & -0.0588 & 0.5172 & 0.6278 & 0.5610 \\
\hline NW & 0.0061 & -0.0567 & 0.4484 & 0.6313 & 0.4309 \\
\hline PM & -0.1815 & -0.1488 & -0.0187 & 0.2596 & -0.0355 \\
\hline SA & 0.2162 & 0.0732 & 0.7517 & 0.8349 & 0.4690 \\
\hline DB & 0.1320 & 0.1664 & 0.1933 & 0.2335 & 0.4115 \\
\hline
\end{tabular}

which corresponds to CCSF level 2, while AP mainly requires level 4 corresponding to CCSF level 3.

- Advanced level examinations require knowledge level 4 and skill level 5. These levels correspond to CCSF level 4.

The readers can find a list of ICTBOK areas for each examination category of JITEE in Appendix A.3. The areas are sorted in the descending order of importance level. The estimated requirement levels are associated for knowledge and skill.

\section{Comparison of J07 Domains and JITEE Ex- amination Categories}

\subsection{Similarity Analysis Based on Importance Level}

Characteristics of a J07 domain or a JITEE examination category can be represented by a 23 dimensional vector, i.e., importance levels (weights) of the fields. Then we can evaluate the similarity among them by computing the correlation coefficient of the corresponding vectors. They are represented separately in Table 8, Table 9 and Table 10. A pair is represented using italic font if the correlation coefficient is larger than 0.7.

The readers can easily observe that SE and IS are similar within J07 domains. IP, FE and AP are similar within JITEE. SC, NW and SA are also similar. There is a similarity between IS and FE, AP and SA in JITEE so that a mismatch is rather small between these combinations. This implies that there is a common policy or direction between the similar pair. Such a comparison becomes possible by using our approach since they are now described using the same terminology.
Table 11 Overall satisfaction ratio of J07 domains against JITEE examination categories (level 1 to 3 )

\begin{tabular}{c|c|c|c}
\hline \hline \multirow{2}{*}{$\begin{array}{c}\text { J07 } \\
\text { Domain }\end{array}$} & \multicolumn{3}{|c}{ Satisfaction Ratio (\%) } \\
\cline { 2 - 4 } & IP & FE & AP \\
\hline CS & 41.11 & 31.56 & 14.72 \\
\hline CE & 58.89 & 38.55 & 18.30 \\
\hline SE & 45.56 & 31.28 & 14.06 \\
\hline IS & 76.67 & 47.49 & 23.21 \\
\hline IT & 62.22 & 55.31 & 28.91 \\
\hline
\end{tabular}

\subsection{Comparison Based on Requirement Level Satisfaction Ratio}

CCSF level 2 corresponds to the level of college graduates willing to be IT engineers as explained in Table 2. CCSF levels 1 and 3 correspond to the level of non-ICT college graduate and ICT graduate student. Thus it is valuable to compare J07 domains and JITEE-IP, FE, AP examinations.

Table 11 represents the overall satisfaction ratio of each J07 domain against JITEE examination category. The satisfaction ratio is defined by the following formula.

$$
\frac{\sum w_{\text {JITEE }} \times \min \left(r, r_{\text {JITEE }}\right)}{\sum w_{\text {JITEE }} \times r_{\text {JITEE }}}
$$

In the above formula, $r$ is the requirement level of a J07 domain at each area. WITEE $_{\text {JIT }} r_{\text {JITEE }}$ are the importance and the requirement levels of a JITEE examination at the same area. The weighted sums of the knowledge and skill requirement levels are 202 and 156 respectively in case of the FE examination. Thus the weight of the skill requirement is $77 \%$ of the knowledge requirement.

It can be observed from Table 11 that the requirement of J07 domains is generally less than the requirement of the FE examination. One reason of this is that JITEE syllabus is seldom referenced during J07 curriculum development process. In this sense, relationship analysis is important for future development of computing curriculum standard and ICT examination. Another reason is that J07 only defines one-year technical education for ICT graduates and does not include education through a graduation research project. The requirement gap should be considered to design a concrete curriculum at each university. Although it is not mandatory for a university to achieve FE level, the FE level can be considered as a society's expectation provided by the Japanese government. It is also valuable for a student to study for JITEE examination as career development. Thus there is a reason or social responsibility for an ICT university to refer the JITEE-FE requirement. Simila rly, JITEE-AP (CCSF level 3) can be considered as a society's expectation for a graduate student having majored in ICT. 

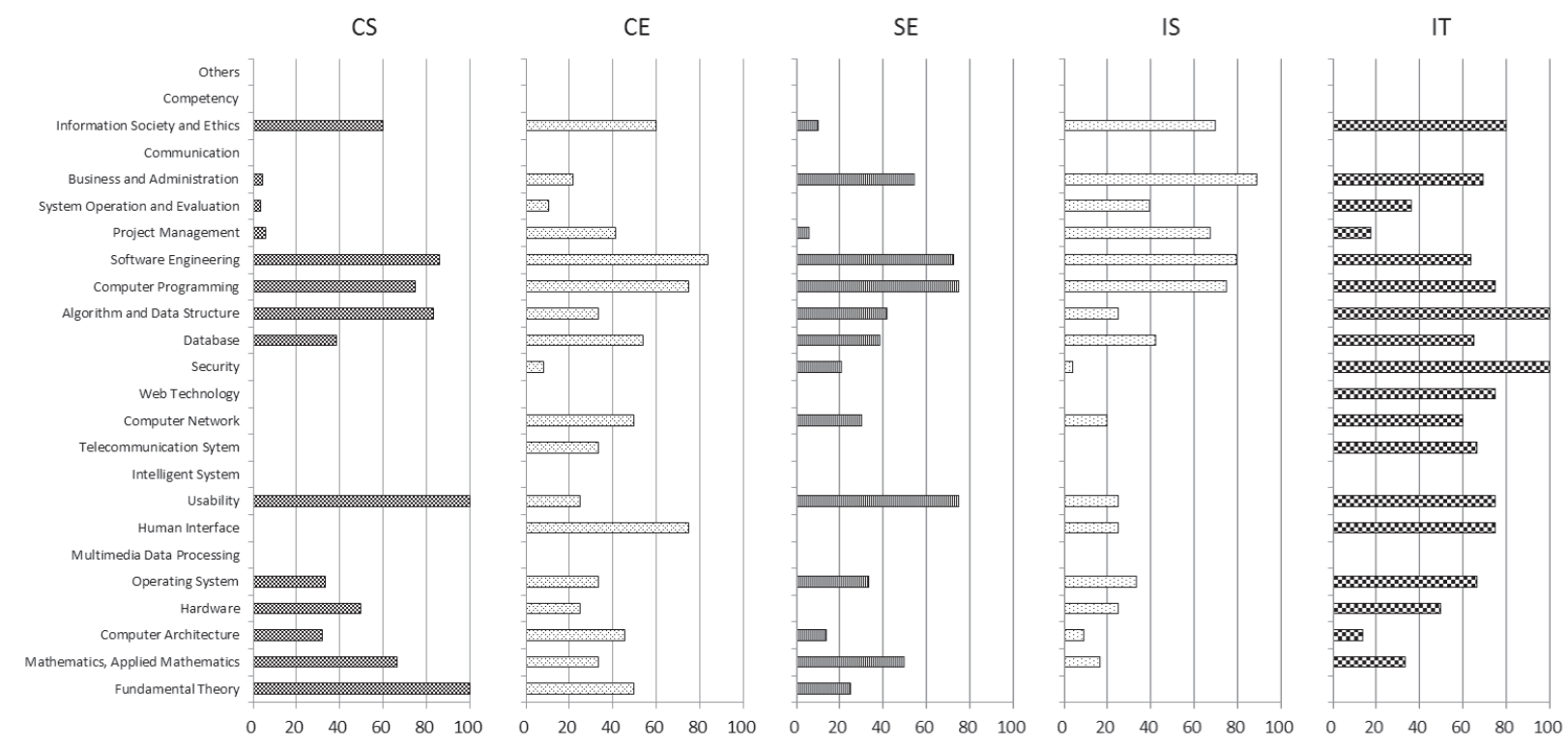

Fig. 4 Satisfaction ratio of J07 domains against JITEE-FE examination at each field.

Figure 4 illustrates the satisfaction ratio of each ICTBOK field of each J07 domain against the JITEE-FE examination. The satisfaction ratio is calculated for the areas belonging to each field. A quantitative comparison of the J07 domains and the FE examination becomes possible by observing Fig. 4. Particularly strong and weak fields of a J07 domain are visualized from the viewpoint of the FE examination.

Note that the weights of the following three fields are zero in the case of JITEE-FE examination so that the satisfaction ratio of the fields cannot be defined.

- Intelligent System

- Communication

- Competency

Considering the fact that the importance of "Communication" and "Competency" are high at our requirement level survey project from the industry [7], we can say that the FE examination also has some weak points as explained above. The readers can refer to Fig. 3 for the entire distribution of the weights of the FE examination. We can observe from Fig. 4 that the maximum satisfaction ratio is greater than $60 \%$ for most of the fields. The exceptions are the following three fields.

- Computer Architecture

- Multimedia Data Processing

- System Operation and Evaluation

These three fields are the common candidate for future improvement of the J07 domains. From the other viewpoint, universities can develop their own curriculum by integrating the desired portion of J07 domains.

We do not compare J07 domains against JITEE advanced level examinations in this paper. There are some departments or laboratories that teach knowledge and skill of the advanced level examination. Such education often contains a practical training, such as PBL or internship program, at a real world environment. Such effort is valuable to prepare students to quickly achieve CCSF level 4 for which a 5-year working experience is typically required. It is usually difficult to achieve CCSF level 4 only by college education.

\section{Conclusion}

In this paper, J07 domains and JITEE examination categories are analyzed using ICTBOK as a common vocabulary. As a result, the relationship among J07 domains and JITEE examination categories is clarified. Such a clarification of the relationship is a first step to build an effective education system to develop a high level ICT professional with the cooperation of academia and industry.

We also collect requirement data from the industry [7] and achievement data from the academia [8] respectively. Since the requirement and achievement data are collected using ICTBOK, the relationship between them can be analyzed quantitatively. Furthermore it is also possible to compare such data with the analysis result obtained in this paper. We have developed a Webbased system named "cresie" in order to collect requirement and achievement data [9]. The comparison function will be added to the system in the near future.

The authors believe that a common terminology and a quantitative analysis of education outcome is necessary to promote the cooperation between the academia and the industry. Although it is not necessary for an education program to teach the entire requirement, an educational institution should understand the background or reason of the requirement and try to improve their education program. It is also true that the industry should understand the effort of the academia and provide a reasonable requirement. Our work is a start point of such effort.

It is often said that there is a mismatch between the industry's requirement and the university's achievement in ICT education. Our research focuses on this point and aims at clarifying the mismatch. In this paper, we analyze the J07 curriculum standard to compare requirements of J07 domains with the industry's requirement. The relationship among J07 domains is clarified using the 
importance and requirement levels. It is observed that the J07 domains should also focus on competences so that the graduates of the domain can achieve competency requirements.

Acknowledgments This research is supported by the Japanese Grants-in-Aid for Scientific Research (Grant number 22500858).

\section{References}

[1] Information Procession Society of Japan: Computing Curriculum Standard J07 (2008) (in Japanese), available from 〈http://www.ipsj.or. jp/12kyoiku/J07/J0720090407.html〉 (accessed 2013-10-12).

[2] ACM: AIS and IEEE-CS, Curricula Recommendations, available from 〈http://www.acm.org/education/education/ curricula-recommendations $\rangle$ (accessed 2013-10-12).

[3] Kakeshita, T. and Yamamoto, M.: A unified BOK for IT professionals based on various IT skill standards and an analysis of educational programs using the BOK, IPSJ Journal, Vol.49, No.10, pp.3377-3387 (2008) (in Japanese).

[4] SFIA Foundation: Skills Framework for the Information Age (SFIA 5) (2011), available from 〈http://www.sfia.org.uk/〉 (accessed 2013-1012).

[5] IPA: Common Career/Skill Framework, available from 〈http://www. ipa.go.jp/english/humandev/forth.html $\rangle$ (accessed 2013-10-12).

[6] IPA: JITEE syllabus (May 2012) (in Japanese) available from 〈https://www.jitec.ipa.go.jp/1_04hanni_sukiru/_index_hanni_skill. html $\rangle$ (accessed 2013-10-12).

[7] Kakeshita, T. and Ohtsuki, M.: Follow up survey of computing curriculum standard J07: Requirement level analysis of industry, IASTED International Conference Technology for Education and Learning (TEL 2011), Beijing, China, pp.138-145 (Oct. 2011).

[8] Ohtsuki, M. and Kakeshita, T.: J07 follow-up survey: Achievement level analysis of colleges and students, Computers and Advanced Technology in Education (CATE 2012), 774-067, Napoli, Italy, pp.1-9 (June 2012).

[9] Kakeshita, T. and Ohtsuki, M.: A web-based survey system to analyze outcomes and requirements: A case for college level education and professional development in ICT, 9th International Conference on Education and Information Systems, Technologies and Applications (EISTA 2011), pp.82-87 (July 2011).

\section{Appendix}

\section{A.1 ICTBOK}

\begin{tabular}{|c|c|}
\hline Field & Area \\
\hline \multirow{7}{*}{$\begin{array}{l}\text { Fundamental } \\
\text { Theory } \\
\text { (FND) }\end{array}$} & Mathematical Logic \\
\hline & $\begin{array}{l}\text { Language Theory, Automaton, Theory of Com- } \\
\text { putation }\end{array}$ \\
\hline & Computational Complexity Theory \\
\hline & Numerical Analysis \\
\hline & Simulation \\
\hline & Digital Representation of Information \\
\hline & Representation of Numeric and Character Data \\
\hline \multirow{5}{*}{$\begin{array}{l}\text { Mathematics, } \\
\text { Applied } \\
\text { Mathematics } \\
\text { (MATH) }\end{array}$} & Calculus \\
\hline & Linear Algebra \\
\hline & Discrete Mathematics \\
\hline & Probability Theory and Statistics \\
\hline & Optimization \\
\hline \multirow{9}{*}{$\begin{array}{c}\text { Computer } \\
\text { Architecture } \\
\text { (ARCH) }\end{array}$} & General Purpose Processor \\
\hline & Special Purpose Processor \\
\hline & Architecture Description Language \\
\hline & Memory Architecture, Memory Device \\
\hline & Hardware Interface \\
\hline & Instrumental Engineering \\
\hline & Control Engineering \\
\hline & Embedded Systems \\
\hline & High Performance Computing \\
\hline
\end{tabular}

\begin{tabular}{|c|c|}
\hline Field & Area \\
\hline \multirow{7}{*}{$\begin{array}{l}\text { Hardware } \\
\text { (HW) }\end{array}$} & Electric Circuit \\
\hline & Electronic Circuit \\
\hline & Digital Signal Processing \\
\hline & $\mathrm{I} / \mathrm{O}$ \\
\hline & VLSI Description Language \\
\hline & Logic Circuit Design \\
\hline & VLSI Design \\
\hline \multirow{5}{*}{$\begin{array}{l}\text { Operating } \\
\text { System } \\
\text { (OS) }\end{array}$} & Basic Concepts \\
\hline & $\begin{array}{l}\text { Organization and Evaluation of Operating Sys- } \\
\text { tem }\end{array}$ \\
\hline & Application of Operating System \\
\hline & Implementation of Operating System \\
\hline & Specific OS \\
\hline \multirow{8}{*}{$\begin{array}{l}\text { Multimedia } \\
\text { Data } \\
\text { Processing } \\
\text { (MMDP) }\end{array}$} & Compression of Multimedia Data \\
\hline & Multimedia Data Management \\
\hline & Computer Graphics \\
\hline & Image Processing and Recognition \\
\hline & Sound Processing and Recognition \\
\hline & Design and Development of Digital Contents \\
\hline & Evaluation of Digital Contents \\
\hline & Application of Multimedia Data Processing \\
\hline \multirow{3}{*}{$\begin{array}{l}\text { Human } \\
\text { Interface } \\
\text { (HUI) }\end{array}$} & Ergonomics \\
\hline & Cognitive Engineering \\
\hline & Interaction and HMI \\
\hline \multirow[t]{2}{*}{ Usability } & Usability Design \\
\hline & Usability Evaluation \\
\hline \multirow{6}{*}{$\begin{array}{l}\text { Intelligent } \\
\text { System } \\
\text { (INTL) }\end{array}$} & Artificial Intelligence \\
\hline & Knowledge Processing \\
\hline & Machine Learning \\
\hline & Natural Language Processing \\
\hline & Pattern Recognition \\
\hline & Robotics \\
\hline \multirow{9}{*}{$\begin{array}{c}\text { Telecommunication } \\
\text { System } \\
\text { (Telecomm) }\end{array}$} & Fundamental of Communication Engineering \\
\hline & Communication Technology \\
\hline & Wireless Communication \\
\hline & Wired Communication \\
\hline & Mobile Communication \\
\hline & QoS Control \\
\hline & Network Device \\
\hline & Law, Social System, Standardization \\
\hline & Development, Management and Operation \\
\hline \multirow{6}{*}{$\begin{array}{l}\text { Computer } \\
\text { Network } \\
\text { (NET) }\end{array}$} & Network Architecture \\
\hline & Implementation of Computer Network \\
\hline & Network Management \\
\hline & Application Management \\
\hline & Distributed System \\
\hline & Network Programming \\
\hline \multirow{8}{*}{$\begin{array}{c}\text { Web } \\
\text { Technology } \\
\text { (WEB) }\end{array}$} & World Wide Web \\
\hline & Web Page Description Language \\
\hline & Protocol, Server \\
\hline & Web Programming \\
\hline & Search Engine Optimization \\
\hline & Weblog \\
\hline & Web Software \\
\hline & Security \\
\hline \multirow[t]{6}{*}{ Security } & Cryptography \\
\hline & Network Security \\
\hline & Authentification \\
\hline & Copyright Management and Protection \\
\hline & Security Management \\
\hline & Security and Society \\
\hline
\end{tabular}




\begin{tabular}{|c|c|}
\hline Field & Area \\
\hline \multirow{10}{*}{$\begin{array}{l}\text { Database } \\
\text { (DB) }\end{array}$} & Database System Concepts \\
\hline & Database Language \\
\hline & DBMS \\
\hline & Transaction Management \\
\hline & Logical Database Design \\
\hline & Physical Database Design \\
\hline & System Development, Management, Operation \\
\hline & Specific DBMS \\
\hline & Information Retrieval \\
\hline & Data Mining \\
\hline \multirow{5}{*}{$\begin{array}{l}\text { Algorithm } \\
\text { and } \\
\text { Data } \\
\text { Structure } \\
\text { (ALGO) }\end{array}$} & Data Structure \\
\hline & Basic Algorithms \\
\hline & Encryption Algorithm \\
\hline & Computation Complexity \\
\hline & Algorithm Design \\
\hline \multirow{5}{*}{$\begin{array}{c}\text { Computer } \\
\text { Programming } \\
\text { (PRG) }\end{array}$} & Foundation of Programming Language \\
\hline & Foundation of Programming \\
\hline & Language Processor \\
\hline & Object Oriented Programming \\
\hline & Specific Programming Language \\
\hline \multirow{11}{*}{$\begin{array}{c}\text { Software } \\
\text { Engineering } \\
\text { (SWE) }\end{array}$} & Requirement Analysis \\
\hline & Structured Analysis and Design \\
\hline & Data Modeling \\
\hline & Data Description Language \\
\hline & Object Oriented Analysis and Design \\
\hline & Software Architecture \\
\hline & Metrics and Measurement \\
\hline & Software Reuse \\
\hline & Software Process \\
\hline & Software Development Environment \\
\hline & Validation and Testing \\
\hline \multirow{6}{*}{$\begin{array}{c}\text { Project } \\
\text { Management } \\
(\mathrm{PM})\end{array}$} & Fundamental Concepts \\
\hline & Time Management \\
\hline & Cost Management \\
\hline & Quality Management \\
\hline & Acquisition Management \\
\hline & Management on Others \\
\hline \multirow{8}{*}{$\begin{array}{c}\text { System } \\
\text { Operation } \\
\text { and } \\
\text { Evaluation } \\
\text { (OPR) }\end{array}$} & Fundamental Concepts \\
\hline & Planning \\
\hline & Operation \\
\hline & Evaluation \\
\hline & Maintenance \\
\hline & Evolution \\
\hline & Specific Information System \\
\hline & Business Process Revolution \\
\hline \multirow{8}{*}{$\begin{array}{c}\text { Business } \\
\text { and } \\
\text { Administration } \\
\text { (Business) }\end{array}$} & Law and Ethics \\
\hline & Business Strategy and Organization \\
\hline & Human Resource Management \\
\hline & Environment Analysis \\
\hline & Accounting \\
\hline & Marketing \\
\hline & Decision Making \\
\hline & Operation \\
\hline \multirow{5}{*}{$\begin{array}{l}\text { Communication } \\
\text { (COMM) }\end{array}$} & Fundamental Concepts \\
\hline & Reading, Writing, Presentation \\
\hline & English \\
\hline & Practical Skill \\
\hline & Negotiation \\
\hline \multirow{4}{*}{$\begin{array}{l}\text { Information } \\
\text { Society } \\
\text { and Ethics } \\
\text { (SOC) }\end{array}$} & Computer Literacy \\
\hline & Intellectual Property \\
\hline & Information Ethics \\
\hline & Law on IT \\
\hline
\end{tabular}

\begin{tabular}{|c|l|}
\hline \hline Field & \multicolumn{1}{|c|}{ Area } \\
\hline Competency & Ability to Act Positively \\
\cline { 2 - 3 } & Ability to Influence People \\
\cline { 2 - 3 } & Ability to Set Goal and to Act \\
\cline { 2 - 3 } & Ability to Analyze Current Status \\
\cline { 2 - 2 } & Planning Ability \\
\cline { 2 - 2 } & Creativity \\
\cline { 2 - 2 } & Ability to Express One's Opinion \\
\cline { 2 - 2 } & Ability to Listen Carefully \\
\cline { 2 - 2 } & Flexibility \\
\cline { 2 - 2 } & Ability to Understand Circumstances \\
\cline { 2 - 2 } & Ability to Keep Rule or Promise \\
\cline { 2 - 2 } & Ability to Manage Stress \\
\hline
\end{tabular}

\section{A.2 Requirement Level Analysis of J07 Do- mains}

We shall illustrate the detailed result of the requirement level analysis in this appendix. The areas are sorted in the order of the importance level (weight) and are illustrated with knowledge and skill requirement levels. The following is the list of abbreviations.

- Req. Level: Requirement level

- KLG: Knowledge

- SKL: Skill

- \%: Importance value $(\%)$

- ACC \%: Accumulated importance value (\%)

- Rank: Ranking of the importance value

The areas are listed until the accumulated importance value exceeds $70 \%$ so that most of the areas having weight appear in the list.

\section{A.2.1 Computer Science (CS)}

\begin{tabular}{|c|c|c|c|c|c|c|}
\hline \multirow[t]{2}{*}{ Field } & \multirow[t]{2}{*}{ Area } & \multicolumn{2}{|c|}{ Req.Level } & \multicolumn{3}{|c|}{ Importance Level } \\
\hline & & KLG & SKL & $\%$ & Acc $\%$ & Rank \\
\hline MATH & $\begin{array}{l}\text { Discrete Math- } \\
\text { ematics }\end{array}$ & 2 & 2 & 7.00 & 7.00 & 1 \\
\hline PRG & $\begin{array}{l}\text { Foundation of } \\
\text { Programming } \\
\text { Language }\end{array}$ & 2 & 2 & 7.00 & 14.01 & 1 \\
\hline ALGO & $\begin{array}{l}\text { Algorithm De- } \\
\text { sign }\end{array}$ & 2 & 2 & 5.84 & 19.84 & 3 \\
\hline ALGO & Data Structure & 2 & 2 & 5.45 & 25.29 & 4 \\
\hline $\mathrm{ARCH}$ & $\begin{array}{l}\text { General Pur- } \\
\text { pose Processor }\end{array}$ & 2 & & 5.06 & 30.35 & 5 \\
\hline OS & Basic Concepts & 2 & & 4.28 & 34.63 & 6 \\
\hline FND & $\begin{array}{l}\text { Language The- } \\
\text { ory, Automa- } \\
\text { ton, Theory of } \\
\text { Computation }\end{array}$ & 2 & 2 & 3.89 & 38.52 & 7 \\
\hline NET & $\begin{array}{l}\text { Network } \\
\text { Architecture }\end{array}$ & 2 & 2 & 3.50 & 42.02 & 8 \\
\hline DB & $\begin{array}{l}\text { Database Sys- } \\
\text { tem Concepts }\end{array}$ & 2 & 2 & 3.11 & 45.14 & 9 \\
\hline ALGO & $\begin{array}{ll}\text { Basic } & \text { Algo- } \\
\text { rithms } & \\
\end{array}$ & 2 & & 3.11 & 48.25 & 9 \\
\hline PRG & $\begin{array}{l}\text { Foundation of } \\
\text { Programming }\end{array}$ & 2 & 2 & 2.72 & 50.97 & 11 \\
\hline SWE & $\begin{array}{l}\text { Object Ori- } \\
\text { ented Analysis } \\
\text { and Design }\end{array}$ & 2 & 2 & 2.72 & 53.70 & 11 \\
\hline FND & $\begin{array}{l}\text { Mathematical } \\
\text { Logic }\end{array}$ & 2 & 2 & 2.33 & 56.03 & 13 \\
\hline
\end{tabular}




\begin{tabular}{|c|c|c|c|c|c|c|}
\hline \multirow[t]{2}{*}{ Field } & \multirow[t]{2}{*}{ Area } & \multicolumn{2}{|c|}{ Req.Level } & \multicolumn{3}{|c|}{ Importance Level } \\
\hline & & KLG & SKL & $\%$ & Acc $\%$ & Rank \\
\hline $\mathrm{ARCH}$ & $\begin{array}{l}\text { Memory Ar- } \\
\text { chitecture, } \\
\text { Memory } \\
\text { Device }\end{array}$ & 2 & & 2.33 & 58.37 & 13 \\
\hline $\begin{array}{l}\text { Hard- } \\
\text { ware }\end{array}$ & $\begin{array}{l}\text { Logic Circuit } \\
\text { Design }\end{array}$ & 2 & 2 & 2.33 & 60.70 & 13 \\
\hline PRG & $\begin{array}{l}\text { Object } \begin{array}{l}\text { Ori- } \\
\text { ented } \\
\text { gramming }\end{array} \\
\end{array}$ & 2 & 2 & 2.33 & 63.04 & 13 \\
\hline SWE & $\begin{array}{l}\text { Software } \\
\text { Reuse }\end{array}$ & 2 & & 2.33 & 65.37 & 13 \\
\hline SWE & $\begin{array}{l}\text { Requirement } \\
\text { Analysis }\end{array}$ & 2 & 2 & 1.95 & 67.32 & 18 \\
\hline $\begin{array}{l}\text { Busi- } \\
\text { ness }\end{array}$ & $\begin{array}{l}\text { Decision Mak- } \\
\text { ing }\end{array}$ & 2 & & 1.95 & 69.26 & 18 \\
\hline MATH & $\begin{array}{l}\text { Probability } \\
\text { Theory and } \\
\text { Statistics }\end{array}$ & 2 & 2 & 1.56 & 70.82 & 20 \\
\hline OS & $\begin{array}{l}\text { Implementa- } \\
\text { tion of Operat- } \\
\text { ing System }\end{array}$ & 2 & & 1.56 & 72.37 & 20 \\
\hline $\begin{array}{l}\text { Usa- } \\
\text { bility }\end{array}$ & $\begin{array}{l}\text { Usability } \\
\text { Design }\end{array}$ & 2 & 2 & 1.56 & 73.93 & 20 \\
\hline ALGO & $\begin{array}{l}\text { Computation } \\
\text { Complexity }\end{array}$ & 2 & & 1.56 & 75.49 & 20 \\
\hline PRG & $\begin{array}{l}\text { Language Pro- } \\
\text { cessor }\end{array}$ & 2 & 2 & 1.56 & 77.04 & 20 \\
\hline SWE & $\begin{array}{l}\text { Validation and } \\
\text { Testing }\end{array}$ & 2 & 2 & 1.56 & 78.60 & 20 \\
\hline
\end{tabular}

\section{A.2.2 Computer Engineering (CE)}

\begin{tabular}{|c|c|c|c|c|c|c|}
\hline \multirow[t]{2}{*}{ Field } & \multirow[t]{2}{*}{ Area } & \multicolumn{2}{|c|}{ Req.Level } & \multicolumn{3}{|c|}{ Importance Level } \\
\hline & & KLG & SKL & $\%$ & Acc \% & Rank \\
\hline HW & Electric Circuit & 2 & & 7.26 & 7.26 & 1 \\
\hline MATH & $\begin{array}{l}\text { Probability } \\
\text { Theory and } \\
\text { Statistics }\end{array}$ & 2 & & 6.60 & 13.86 & 2 \\
\hline MATH & $\begin{array}{l}\text { Discrete Math- } \\
\text { ematics }\end{array}$ & 2 & & 5.28 & 19.14 & 3 \\
\hline HW & $\begin{array}{l}\text { Logic Circuit } \\
\text { Design }\end{array}$ & 2 & 2 & 5.28 & 24.42 & 3 \\
\hline FND & $\begin{array}{l}\text { Digital Repre- } \\
\text { sentation of In- } \\
\text { formation }\end{array}$ & 2 & 2 & 4.95 & 29.37 & 5 \\
\hline $\mathrm{ARCH}$ & $\begin{array}{l}\text { General Pur- } \\
\text { pose Processor }\end{array}$ & 2 & & 4.95 & 34.32 & 5 \\
\hline HW & VLSI Design & 2 & 2 & 4.95 & 39.27 & 5 \\
\hline $\begin{array}{l}\text { Busi- } \\
\text { ness }\end{array}$ & $\begin{array}{l}\text { Decision Mak- } \\
\text { ing }\end{array}$ & 2 & & 3.96 & 43.23 & 8 \\
\hline OS & Basic Concepts & 2 & & 3.30 & 46.53 & 9 \\
\hline ALGO & $\begin{array}{l}\text { Algorithm De- } \\
\text { sign }\end{array}$ & & & 2.64 & 49.17 & 10 \\
\hline SOC & $\begin{array}{l}\text { Information } \\
\text { Ethics }\end{array}$ & 2 & & 2.31 & 51.49 & 11 \\
\hline $\mathrm{ARCH}$ & $\begin{array}{l}\text { Memory Ar- } \\
\text { chitecture, } \\
\text { Memory } \\
\text { Device }\end{array}$ & 2 & & 1.98 & 53.47 & 12 \\
\hline OS & $\begin{array}{l}\text { Implementa- } \\
\text { tion of Operat- } \\
\text { ing System }\end{array}$ & 2 & & 1.98 & 55.45 & 12 \\
\hline INTL & $\begin{array}{l}\text { Knowledge } \\
\text { Processing }\end{array}$ & 2 & & 1.98 & 57.43 & 12 \\
\hline DB & DBMS & 2 & & 1.98 & 59.41 & 12 \\
\hline
\end{tabular}

\begin{tabular}{|l|l|c|c|c|c|c|}
\hline \hline Field & Area & \multicolumn{2}{|c|}{ Req.Level } & \multicolumn{3}{|c|}{ Importance Level } \\
\cline { 3 - 7 } & & KLG & SKL & $\%$ & Acc $\%$ & Rank \\
\hline PRG & $\begin{array}{l}\text { Foundation of } \\
\text { Programming } \\
\text { Language }\end{array}$ & 2 & 2 & 1.98 & 61.39 & 12 \\
\hline SWE & $\begin{array}{l}\text { Software De- } \\
\text { velopment } \\
\text { Environment }\end{array}$ & 2 & 2 & 1.98 & 63.37 & 12 \\
\hline NET & $\begin{array}{l}\text { Network } \\
\text { Architecture }\end{array}$ & 2 & & 1.65 & 65.02 & 18 \\
\hline DB & $\begin{array}{l}\text { Logical } \\
\text { Database } \\
\text { Design }\end{array}$ & 2 & 2 & 1.65 & 66.67 & 18 \\
\hline SWE & $\begin{array}{l}\text { Validation and } \\
\text { Testing }\end{array}$ & 2 & 2 & 1.65 & 68.32 & 18 \\
\hline
\end{tabular}

\section{A.2.3 Software Engineering (SE)}

\begin{tabular}{|c|c|c|c|c|c|c|}
\hline \multirow[t]{2}{*}{ Field } & \multirow[t]{2}{*}{ Area } & \multicolumn{2}{|c|}{ Req.Level } & \multicolumn{3}{|c|}{ Importance Level } \\
\hline & & KLG & SKL & $\%$ & Acc $\%$ & Rank \\
\hline SWE & $\begin{array}{l}\text { Validation and } \\
\text { Testing }\end{array}$ & 2 & 2 & 11.43 & 11.43 & 1 \\
\hline SWE & $\begin{array}{l}\text { Software } \\
\text { Architecture }\end{array}$ & 2 & 2 & 10.00 & 21.43 & 2 \\
\hline SWE & $\begin{array}{l}\text { Requirement } \\
\text { Analysis }\end{array}$ & 2 & 2 & 8.57 & 30.00 & 3 \\
\hline $\begin{array}{l}\text { Usa- } \\
\text { bility }\end{array}$ & $\begin{array}{l}\text { Usability } \\
\text { Design }\end{array}$ & 2 & 1 & 5.71 & 35.71 & 4 \\
\hline SWE & $\begin{array}{l}\text { Software Pro- } \\
\text { cess }\end{array}$ & 2 & & 5.71 & 41.43 & 4 \\
\hline MATH & $\begin{array}{l}\text { Discrete Math- } \\
\text { ematics }\end{array}$ & 2 & & 4.29 & 45.71 & 6 \\
\hline PRG & $\begin{array}{l}\text { Foundation of } \\
\text { Programming } \\
\text { Language }\end{array}$ & 2 & 2 & 4.29 & 50.00 & 6 \\
\hline $\mathrm{PM}$ & $\begin{array}{l}\text { Fundamental } \\
\text { Concepts }\end{array}$ & 2 & & 4.29 & 54.29 & 6 \\
\hline FND & $\begin{array}{l}\text { Mathematical } \\
\text { Logic }\end{array}$ & 2 & 1 & 2.86 & 57.14 & 9 \\
\hline MATH & Linear Algebra & 2 & & 2.86 & 60.00 & 9 \\
\hline OS & Basic Concepts & 2 & 2 & 2.86 & 62.86 & 9 \\
\hline NET & $\begin{array}{l}\text { Network } \\
\text { Architecture }\end{array}$ & 2 & & 2.86 & 65.71 & 9 \\
\hline ALGO & $\begin{array}{ll}\text { Basic } & \text { Algo- } \\
\text { rithms } & \\
\end{array}$ & 2 & 2 & 2.86 & 68.57 & 9 \\
\hline PRG & $\begin{array}{l}\text { Foundation of } \\
\text { Programming }\end{array}$ & 2 & 2 & 2.86 & 71.43 & 9 \\
\hline SWE & Data Modeling & 2 & & 2.86 & 74.29 & 9 \\
\hline SWE & $\begin{array}{l}\text { Object Ori- } \\
\text { ented Analysis } \\
\text { and Design }\end{array}$ & 2 & & 2.86 & 77.14 & 9 \\
\hline SWE & $\begin{array}{l}\text { Software } \\
\text { Reuse }\end{array}$ & 2 & & 2.86 & 80.00 & 9 \\
\hline $\begin{array}{l}\text { Busi- } \\
\text { ness }\end{array}$ & Operation & 2 & 2 & 2.86 & 82.86 & 9 \\
\hline FND & $\begin{array}{l}\text { Language The- } \\
\text { ory, Automa- } \\
\text { ton, Theory of } \\
\text { Computation }\end{array}$ & 2 & 1 & 1.43 & 84.29 & 19 \\
\hline MATH & $\begin{array}{l}\text { Probability } \\
\text { Theory and } \\
\text { Statistics }\end{array}$ & 2 & 2 & 1.43 & 85.71 & 19 \\
\hline NET & $\begin{array}{l}\text { Implementa- } \\
\text { tion of Com- } \\
\text { puter Network }\end{array}$ & 2 & 1 & 1.43 & 87.14 & 19 \\
\hline $\begin{array}{l}\text { Secu- } \\
\text { rity }\end{array}$ & $\begin{array}{l}\text { Network Secu- } \\
\text { rity }\end{array}$ & 1 & & 1.43 & 88.57 & 19 \\
\hline $\mathrm{DB}$ & $\begin{array}{l}\text { Database Sys- } \\
\text { tem Concepts }\end{array}$ & 1 & 1 & 1.43 & 90.00 & 19 \\
\hline
\end{tabular}




\begin{tabular}{|l|l|c|c|c|c|c|}
\hline \hline \multirow{2}{*}{ Field } & \multirow{2}{*}{ Area } & \multicolumn{2}{|c|}{ Req.Level } & \multicolumn{3}{|c|}{ Importance Level } \\
\cline { 2 - 7 } & & KLG & SKL & $\%$ & Acc \% & Rank \\
\hline DB & $\begin{array}{l}\text { Logical } \\
\text { Database } \\
\text { Design }\end{array}$ & 1 & 1 & 1.43 & 91.43 & 19 \\
\hline DB & $\begin{array}{l}\text { Physical } \\
\text { Database } \\
\text { Design }\end{array}$ & 1 & 1 & 1.43 & 92.86 & 19 \\
\hline SWE & $\begin{array}{l}\text { Structured } \\
\text { Analysis and } \\
\text { Design and }\end{array}$ & 1 & 1 & 1.43 & 94.29 & 19 \\
\hline SWE & $\begin{array}{l}\text { Metrics and } \\
\text { Measurement }\end{array}$ & 1 & & 1.43 & 95.71 & 19 \\
\hline SWE & $\begin{array}{l}\text { Software De- } \\
\text { velopment } \\
\text { Environment }\end{array}$ & 1 & & 1.43 & 97.14 & 19 \\
\hline $\begin{array}{l}\text { Busi- } \\
\text { ness }\end{array}$ & $\begin{array}{l}\text { Decision Mak- } \\
\text { ing }\end{array}$ & 1 & & 1.43 & 98.57 & 19 \\
\hline $\begin{array}{l}\text { COM- } \\
\text { M }\end{array}$ & Practical Skill & 2 & 1 & 1.43 & 100.00 & 19 \\
\hline
\end{tabular}

\section{A.2.4 Information Systems (IS)}

\begin{tabular}{|c|c|c|c|c|c|c|}
\hline \multirow[t]{2}{*}{ Field } & \multirow[t]{2}{*}{ Area } & \multicolumn{2}{|c|}{ Req.Level } & \multicolumn{3}{|c|}{ Importance Level } \\
\hline & & KLG & SKL & $\%$ & Acc $\%$ & Rank \\
\hline OPR & $\begin{array}{l}\text { Fundamental } \\
\text { Concepts }\end{array}$ & 2 & & 7.53 & 7.53 & 1 \\
\hline $\begin{array}{l}\text { COM- } \\
\mathrm{M}\end{array}$ & Practical Skill & 2 & 2 & 6.45 & 13.98 & 2 \\
\hline SWE & $\begin{array}{l}\text { Software Pro- } \\
\text { cess }\end{array}$ & 2 & 2 & 5.38 & 19.35 & 3 \\
\hline $\begin{array}{l}\text { Busi- } \\
\text { ness }\end{array}$ & Operation & 2 & 2 & 5.38 & 24.73 & 3 \\
\hline SWE & $\begin{array}{l}\text { Metrics and } \\
\text { Measurement }\end{array}$ & 2 & 2 & 4.30 & 29.03 & 5 \\
\hline PM & $\begin{array}{l}\text { Fundamental } \\
\text { Concepts }\end{array}$ & 2 & 2 & 4.30 & 33.33 & 5 \\
\hline SWE & $\begin{array}{l}\text { Structured } \\
\text { Analysis and } \\
\text { Design }\end{array}$ & 2 & 3 & 3.23 & 36.56 & 7 \\
\hline SWE & $\begin{array}{l}\text { Validation and } \\
\text { Testing }\end{array}$ & 2 & & 3.23 & 39.78 & 7 \\
\hline PM & $\begin{array}{l}\text { Management } \\
\text { on Others }\end{array}$ & 2 & 2 & 3.23 & 43.01 & 7 \\
\hline $\begin{array}{l}\text { Busi- } \\
\text { ness }\end{array}$ & $\begin{array}{l}\text { Decision Mak- } \\
\text { ing }\end{array}$ & 2 & 2 & 3.23 & 46.24 & 7 \\
\hline OS & Basic Concepts & 2 & & 2.15 & 48.39 & 11 \\
\hline OS & $\begin{array}{l}\text { Application of } \\
\text { Operating Sys- } \\
\text { tem }\end{array}$ & 2 & 3 & 2.15 & 50.54 & 11 \\
\hline DB & $\begin{array}{l}\text { Database Lan- } \\
\text { guage }\end{array}$ & 2 & 2 & 2.15 & 52.69 & 11 \\
\hline DB & $\begin{array}{l}\text { Logical } \\
\text { Database } \\
\text { Design }\end{array}$ & 2 & 2 & 2.15 & 54.84 & 11 \\
\hline PRG & $\begin{array}{l}\text { Foundation of } \\
\text { Programming } \\
\text { Language }\end{array}$ & 2 & 2 & 2.15 & 56.99 & 11 \\
\hline PRG & $\begin{array}{l}\text { Foundation of } \\
\text { Programming }\end{array}$ & 2 & 2 & 2.15 & 59.14 & 11 \\
\hline PRG & $\begin{array}{lr}\text { Object } & \text { Ori- } \\
\text { ented } & \text { Pro- } \\
\text { gramming } & \end{array}$ & 2 & 2 & 2.15 & 61.29 & 11 \\
\hline SWE & $\begin{array}{l}\text { Requirement } \\
\text { Analysis }\end{array}$ & 2 & 2 & 2.15 & 63.44 & 11 \\
\hline SWE & $\begin{array}{l}\text { Object Ori- } \\
\text { ented Analysis } \\
\text { and Design }\end{array}$ & 2 & 2 & 2.15 & 65.59 & 11 \\
\hline
\end{tabular}

\begin{tabular}{|l|l|c|c|c|c|c|}
\hline \hline Field & Area & \multicolumn{2}{|c|}{ Req.Level } & \multicolumn{3}{|c|}{ Importance Level } \\
\cline { 3 - 7 } & & KLG & SKL & $\%$ & Acc \% & Rank \\
\hline SWE & $\begin{array}{l}\text { Software De- } \\
\text { velopment } \\
\text { Environment }\end{array}$ & 2 & 2 & 2.15 & 67.74 & 11 \\
\hline OPR & Planning & 2 & 2 & 2.15 & 69.89 & 11 \\
\hline $\begin{array}{l}\text { Busi- } \\
\text { ness }\end{array}$ & $\begin{array}{l}\text { Business Strat- } \\
\text { egy and Orga- } \\
\text { nization }\end{array}$ & 2 & & 2.15 & 72.04 & 11 \\
\hline SOC & $\begin{array}{l}\text { Computer Lit- } \\
\text { eracy }\end{array}$ & 2 & & 2.15 & 74.19 & 11 \\
\hline
\end{tabular}

\section{A.2.5 Information Technology (IT)}

\begin{tabular}{|c|c|c|c|c|c|c|}
\hline \multirow[t]{2}{*}{ Field } & \multirow[t]{2}{*}{ Area } & \multicolumn{2}{|c|}{ Req.Level } & \multicolumn{3}{|c|}{ Importance Level } \\
\hline & & KLG & SKL & $\%$ & Acc $\%$ & Rank \\
\hline OPR & $\begin{array}{l}\text { Fundamental } \\
\text { Concepts }\end{array}$ & 2 & 1 & 5.26 & 5.26 & 1 \\
\hline $\begin{array}{l}\text { Busi- } \\
\text { ness }\end{array}$ & $\begin{array}{l}\text { Decision Mak- } \\
\text { ing }\end{array}$ & 2 & 2 & 5.26 & 10.53 & 1 \\
\hline WEB & $\begin{array}{l}\text { Web Program- } \\
\text { ming }\end{array}$ & 2 & 2 & 3.86 & 14.39 & 3 \\
\hline OS & $\begin{array}{l}\text { Organization } \\
\text { and Evaluation } \\
\text { of Operating } \\
\text { System }\end{array}$ & 2 & 2 & 3.51 & 17.89 & 4 \\
\hline $\begin{array}{l}\text { Secu- } \\
\text { rity }\end{array}$ & $\begin{array}{l}\text { Security Man- } \\
\text { agement }\end{array}$ & 2 & 2 & 3.51 & 21.40 & 4 \\
\hline DB & $\begin{array}{l}\text { Database Lan- } \\
\text { guage }\end{array}$ & 2 & 2 & 3.16 & 24.56 & 6 \\
\hline PRG & $\begin{array}{l}\text { Foundation of } \\
\text { Programming }\end{array}$ & 2 & 2 & 3.16 & 27.72 & 6 \\
\hline PRG & $\begin{array}{ll}\text { Object } & \text { Ori- } \\
\text { ented } & \text { Pro- } \\
\text { gramming } & \end{array}$ & 2 & 2 & 3.16 & 30.88 & 6 \\
\hline $\begin{array}{l}\text { Usa- } \\
\text { bility }\end{array}$ & $\begin{array}{l}\text { Usability } \\
\text { Design }\end{array}$ & 2 & 1 & 2.81 & 33.68 & 9 \\
\hline $\begin{array}{l}\text { Secu- } \\
\text { rity }\end{array}$ & $\begin{array}{l}\text { Network Secu- } \\
\text { rity }\end{array}$ & 2 & 2 & 2.81 & 36.49 & 9 \\
\hline DB & $\begin{array}{l}\text { Logical } \\
\text { Database } \\
\text { Design }\end{array}$ & 2 & 2 & 2.46 & 38.95 & 11 \\
\hline SWE & $\begin{array}{l}\text { Software } \\
\text { Reuse }\end{array}$ & 2 & 2 & 2.46 & 41.40 & 11 \\
\hline OS & Basic Concepts & 2 & 2 & 2.11 & 43.51 & 13 \\
\hline SWE & $\begin{array}{l}\text { Requirement } \\
\text { Analysis }\end{array}$ & 2 & 2 & 2.11 & 45.61 & 13 \\
\hline SWE & Data Modeling & 2 & 2 & 2.11 & 47.72 & 13 \\
\hline $\begin{array}{l}\text { COM- } \\
\mathrm{M}\end{array}$ & Practical Skill & 2 & 2 & 2.11 & 49.82 & 13 \\
\hline ALGO & Data Structure & 2 & 2 & 1.75 & 51.58 & 17 \\
\hline ALGO & $\begin{array}{l}\text { Basic } \\
\text { rithms }\end{array}$ & 2 & 2 & 1.75 & 53.33 & 17 \\
\hline PRG & $\begin{array}{l}\text { Foundation of } \\
\text { Programming } \\
\text { Language }\end{array}$ & 2 & 2 & 1.75 & 55.09 & 17 \\
\hline SWE & $\begin{array}{l}\text { Data Descrip- } \\
\text { tion Language }\end{array}$ & 2 & 2 & 1.75 & 56.84 & 17 \\
\hline PM & $\begin{array}{l}\text { Fundamental } \\
\text { Concepts }\end{array}$ & 2 & 2 & 1.75 & 58.60 & 17 \\
\hline $\begin{array}{l}\text { Busi- } \\
\text { ness }\end{array}$ & $\begin{array}{l}\text { Business Strat- } \\
\text { egy and Orga- } \\
\text { nization }\end{array}$ & 2 & 1 & 1.75 & 60.35 & 17 \\
\hline NET & $\begin{array}{l}\text { Network } \\
\text { Architecture }\end{array}$ & 2 & 1 & 1.40 & 61.75 & 23 \\
\hline WEB & $\begin{array}{l}\text { Web Page De- } \\
\text { scription Lan- } \\
\text { guage }\end{array}$ & 2 & 2 & 1.40 & 63.16 & 23 \\
\hline
\end{tabular}




\begin{tabular}{|l|l|c|c|c|c|c|}
\hline \hline \multirow{2}{*}{ Field } & \multirow{2}{*}{ Area } & \multicolumn{2}{|c|}{ Req.Level } & \multicolumn{3}{|c|}{ Importance Level } \\
\cline { 3 - 7 } & & KLG & SKL & $\%$ & Acc \% & Rank \\
\hline $\begin{array}{l}\text { Secu- } \\
\text { rity }\end{array}$ & Cryptography & 2 & 1 & 1.40 & 64.56 & 23 \\
\hline DB & DBMS & 2 & 1 & 1.40 & 65.96 & 23 \\
\hline PM & $\begin{array}{l}\text { Acquisition } \\
\text { Management }\end{array}$ & 2 & 2 & 1.40 & 67.37 & 23 \\
\hline OPR & $\begin{array}{l}\text { Specific Infor- } \\
\text { mation System }\end{array}$ & 2 & 1 & 1.40 & 68.77 & 23 \\
\hline SOC & $\begin{array}{l}\text { Information } \\
\text { Ethics }\end{array}$ & 2 & 1 & 1.40 & 70.18 & 23 \\
\hline
\end{tabular}

\section{A.3 Requirement Analysis of JITEE Exami- nation Categories}

The abbreviations of the table are the same as in Appendix A.2. The areas are listed until the accumulated importance value becomes $100 \%$ so that all areas having weight appear in the list.

\section{A.3.1 Information Technology Passport Examination (IP)}

\begin{tabular}{|c|c|c|c|c|c|c|}
\hline \multirow[t]{2}{*}{ Field } & \multirow[t]{2}{*}{ Area } & \multicolumn{2}{|c|}{ Req.Level } & \multicolumn{3}{|c|}{ Importance Level } \\
\hline & & KLG & SKL & $\%$ & Acc $\%$ & Rank \\
\hline $\begin{array}{l}\text { Busi- } \\
\text { ness }\end{array}$ & $\begin{array}{l}\text { Business Strat- } \\
\text { egy and Orga- } \\
\text { nization }\end{array}$ & 1 & & 5.56 & 5.56 & 1 \\
\hline SOC & $\begin{array}{l}\text { Computer Lit- } \\
\text { eracy }\end{array}$ & 2 & 2 & 5.56 & 11.11 & 1 \\
\hline $\begin{array}{l}\text { Busi- } \\
\text { ness }\end{array}$ & $\begin{array}{l}\text { Decision Mak- } \\
\text { ing }\end{array}$ & 1 & & 4.17 & 15.28 & 3 \\
\hline $\begin{array}{l}\text { Busi- } \\
\text { ness }\end{array}$ & Operation & 1 & & 4.17 & 19.44 & 3 \\
\hline HW & $\mathrm{I} / \mathrm{O}$ & 1 & & 2.78 & 22.22 & 5 \\
\hline OS & Basic Concepts & 1 & & 2.78 & 25.00 & 5 \\
\hline $\begin{array}{l}\text { Usa- } \\
\text { bility }\end{array}$ & $\begin{array}{l}\text { Usability } \\
\text { Design }\end{array}$ & 1 & & 2.78 & 27.78 & 5 \\
\hline SWE & $\begin{array}{l}\text { Requirement } \\
\text { Analysis }\end{array}$ & 2 & 2 & 2.78 & 30.56 & 5 \\
\hline SWE & $\begin{array}{l}\text { Software Pro- } \\
\text { cess }\end{array}$ & 1 & & 2.78 & 33.33 & 5 \\
\hline PM & $\begin{array}{l}\text { Fundamental } \\
\text { Concepts }\end{array}$ & 1 & & 2.78 & 36.11 & 5 \\
\hline OPR & Operation & 1 & & 2.78 & 38.89 & 5 \\
\hline OPR & Evaluation & 1 & & 2.78 & 41.67 & 5 \\
\hline OPR & $\begin{array}{l}\text { Specific Infor- } \\
\text { mation System }\end{array}$ & 1 & & 2.78 & 44.44 & 5 \\
\hline $\begin{array}{l}\text { Busi- } \\
\text { ness }\end{array}$ & Law and Ethics & 1 & & 2.78 & 47.22 & 5 \\
\hline $\begin{array}{l}\text { Busi- } \\
\text { ness }\end{array}$ & Marketing & 1 & & 2.78 & 50.00 & 5 \\
\hline SOC & $\begin{array}{l}\text { Information } \\
\text { Ethics }\end{array}$ & 1 & & 2.78 & 52.78 & 5 \\
\hline FND & $\begin{array}{l}\text { Representation } \\
\text { of Numeric } \\
\text { and Character } \\
\text { Data }\end{array}$ & 1 & & 1.39 & 54.17 & 17 \\
\hline MATH & $\begin{array}{l}\text { Discrete Math- } \\
\text { ematics }\end{array}$ & 1 & & 1.39 & 55.56 & 17 \\
\hline MATH & $\begin{array}{l}\text { Probability } \\
\text { Theory and } \\
\text { Statistics }\end{array}$ & 1 & & 1.39 & 56.94 & 17 \\
\hline $\mathrm{ARCH}$ & $\begin{array}{l}\text { General Pur- } \\
\text { pose Processor }\end{array}$ & 1 & & 1.39 & 58.33 & 17 \\
\hline ARCH & $\begin{array}{l}\text { Memory Ar- } \\
\text { chitecture, } \\
\text { Memory } \\
\text { Device }\end{array}$ & 1 & & 1.39 & 59.72 & 17 \\
\hline
\end{tabular}

\begin{tabular}{|c|c|c|c|c|c|c|}
\hline \multirow[t]{2}{*}{ Field } & \multirow[t]{2}{*}{ Area } & \multicolumn{2}{|c|}{ Req.Level } & \multicolumn{3}{|c|}{ Importance Level } \\
\hline & & KLG & SKL & $\%$ & Acc $\%$ & Rank \\
\hline $\mathrm{ARCH}$ & $\begin{array}{l}\text { Embedded } \\
\text { Systems }\end{array}$ & 1 & & 1.39 & 61.11 & 17 \\
\hline $\begin{array}{l}\text { MM- } \\
\text { DP }\end{array}$ & $\begin{array}{l}\text { Compression } \\
\text { of Multimedia } \\
\text { Data }\end{array}$ & 1 & & 1.39 & 62.50 & 17 \\
\hline $\begin{array}{l}\text { MM- } \\
\text { DP }\end{array}$ & $\begin{array}{l}\text { Application } \\
\text { of Multi- } \\
\text { media Data } \\
\text { Processing }\end{array}$ & 1 & & 1.39 & 63.89 & 17 \\
\hline $\begin{array}{l}\text { Tele- } \\
\text { comm }\end{array}$ & $\begin{array}{l}\text { Network } \\
\text { Device }\end{array}$ & 1 & & 1.39 & 65.28 & 17 \\
\hline $\begin{array}{l}\text { Tele- } \\
\text { comm }\end{array}$ & $\begin{array}{l}\text { Law, Social } \\
\text { System, Stan- } \\
\text { dardization }\end{array}$ & 1 & & 1.39 & 66.67 & 17 \\
\hline NET & $\begin{array}{l}\text { Network } \\
\text { Architecture }\end{array}$ & 1 & & 1.39 & 68.06 & 17 \\
\hline NET & $\begin{array}{l}\text { Implementa- } \\
\text { tion of Com- } \\
\text { puter Network }\end{array}$ & 1 & & 1.39 & 69.44 & 17 \\
\hline NET & $\begin{array}{l}\text { Distributed } \\
\text { System }\end{array}$ & 1 & & 1.39 & 70.83 & 17 \\
\hline $\begin{array}{l}\text { Secu- } \\
\text { rity }\end{array}$ & Cryptography & 1 & & 1.39 & 72.22 & 17 \\
\hline $\begin{array}{l}\text { Secu- } \\
\text { rity }\end{array}$ & $\begin{array}{l}\text { Network Secu- } \\
\text { rity }\end{array}$ & 1 & & 1.39 & 73.61 & 17 \\
\hline $\begin{array}{l}\text { Secu- } \\
\text { rity }\end{array}$ & $\begin{array}{l}\text { Authentifica- } \\
\text { tion }\end{array}$ & 1 & & 1.39 & 75.00 & 17 \\
\hline $\begin{array}{l}\text { Secu- } \\
\text { rity }\end{array}$ & $\begin{array}{l}\text { Security Man- } \\
\text { agement }\end{array}$ & 1 & & 1.39 & 76.39 & 17 \\
\hline DB & $\begin{array}{l}\text { Database Sys- } \\
\text { tem Concepts }\end{array}$ & 1 & & 1.39 & 77.78 & 17 \\
\hline DB & $\begin{array}{l}\text { Database Lan- } \\
\text { guage }\end{array}$ & 1 & & 1.39 & 79.17 & 17 \\
\hline DB & DBMS & 1 & & 1.39 & 80.56 & 17 \\
\hline DB & $\begin{array}{l}\text { Transaction } \\
\text { Management }\end{array}$ & 1 & & 1.39 & 81.94 & 17 \\
\hline DB & $\begin{array}{l}\text { Logical } \\
\text { Database } \\
\text { Design }\end{array}$ & 1 & & 1.39 & 83.33 & 17 \\
\hline ALGO & Data Structure & 1 & & 1.39 & 84.72 & 17 \\
\hline ALGO & $\begin{array}{l}\text { Basic Algo- } \\
\text { rithms }\end{array}$ & 1 & & 1.39 & 86.11 & 17 \\
\hline PRG & $\begin{array}{l}\text { Foundation of } \\
\text { Programming } \\
\text { Language }\end{array}$ & 1 & & 1.39 & 87.50 & 17 \\
\hline PRG & $\begin{array}{l}\text { Foundation of } \\
\text { Programming }\end{array}$ & 1 & & 1.39 & 88.89 & 17 \\
\hline PRG & $\begin{array}{l}\text { Specific Pro- } \\
\text { gramming } \\
\text { Language }\end{array}$ & 1 & & 1.39 & 90.28 & 17 \\
\hline SWE & $\begin{array}{l}\text { Metrics and } \\
\text { Measurement }\end{array}$ & 1 & & 1.39 & 91.67 & 17 \\
\hline PM & $\begin{array}{l}\text { Acquisition } \\
\text { Management }\end{array}$ & 1 & & 1.39 & 93.06 & 17 \\
\hline OPR & $\begin{array}{l}\text { Fundamental } \\
\text { Concepts }\end{array}$ & 1 & & 1.39 & 94.44 & 17 \\
\hline OPR & Planning & 1 & & 1.39 & 95.83 & 17 \\
\hline $\begin{array}{l}\text { Busi- } \\
\text { ness }\end{array}$ & $\begin{array}{lr}\begin{array}{l}\text { Human } \\
\text { source } \\
\text { agement }\end{array} & \text { Man- } \\
\text { agement }\end{array}$ & 1 & & 1.39 & 97.22 & 17 \\
\hline $\begin{array}{l}\text { Busi- } \\
\text { ness }\end{array}$ & Accounting & 1 & & 1.39 & 98.61 & 17 \\
\hline SOC & $\begin{array}{l}\text { Intellectual } \\
\text { Property }\end{array}$ & 1 & & 1.39 & 100.00 & 17 \\
\hline
\end{tabular}


A.3.2 Fundamental Information Technology Engineer Examination (FE)

\begin{tabular}{|c|c|c|c|c|c|c|}
\hline \multirow[t]{2}{*}{ Field } & \multirow[t]{2}{*}{ Area } & \multicolumn{2}{|c|}{ Req.Level } & \multicolumn{3}{|c|}{ Importance Level } \\
\hline & & KLG & SKL & $\%$ & Acc $\%$ & Rank \\
\hline $\begin{array}{l}\text { Busi- } \\
\text { ness }\end{array}$ & Operation & 2 & 2 & 5.94 & 5.94 & 1 \\
\hline OPR & Operation & 2 & 2 & 4.95 & 10.89 & 2 \\
\hline $\begin{array}{l}\text { Busi- } \\
\text { ness }\end{array}$ & $\begin{array}{l}\text { Business Strat- } \\
\text { egy and Orga- } \\
\text { nization }\end{array}$ & 2 & & 4.95 & 15.84 & 2 \\
\hline $\begin{array}{l}\text { Secu- } \\
\text { rity }\end{array}$ & $\begin{array}{l}\text { Security Man- } \\
\text { agement }\end{array}$ & 2 & 2 & 3.96 & 19.80 & 4 \\
\hline PM & $\begin{array}{l}\text { Management } \\
\text { on Others }\end{array}$ & 2 & 2 & 3.96 & 23.76 & 4 \\
\hline OPR & Planning & 2 & 2 & 3.96 & 27.72 & 4 \\
\hline SWE & $\begin{array}{l}\text { Requirement } \\
\text { Analysis }\end{array}$ & 2 & 2 & 2.97 & 30.69 & 7 \\
\hline SWE & $\begin{array}{l}\text { Validation and } \\
\text { Testing }\end{array}$ & 2 & 2 & 2.97 & 33.66 & 7 \\
\hline OPR & Evaluation & 2 & 2 & 2.97 & 36.63 & 7 \\
\hline OPR & $\begin{array}{l}\text { Specific Infor- } \\
\text { mation System }\end{array}$ & 2 & & 2.97 & 39.60 & 7 \\
\hline $\mathrm{ARCH}$ & $\begin{array}{l}\text { Embedded } \\
\text { Systems }\end{array}$ & 2 & & 1.98 & 41.58 & 11 \\
\hline HW & $\mathrm{I} / \mathrm{O}$ & 2 & 2 & 1.98 & 43.56 & 11 \\
\hline PRG & $\begin{array}{l}\text { Foundation of } \\
\text { Programming }\end{array}$ & 2 & 2 & 1.98 & 45.54 & 11 \\
\hline SWE & $\begin{array}{l}\text { Software Pro- } \\
\text { cess }\end{array}$ & 2 & 2 & 1.98 & 47.52 & 11 \\
\hline SWE & $\begin{array}{l}\text { Software De- } \\
\text { velopment } \\
\text { Environment }\end{array}$ & 2 & 2 & 1.98 & 49.50 & 11 \\
\hline PM & $\begin{array}{l}\text { Acquisition } \\
\text { Management }\end{array}$ & 2 & & 1.98 & 51.49 & 11 \\
\hline SOC & $\begin{array}{l}\text { Intellectual } \\
\text { Property }\end{array}$ & 2 & 2 & 1.98 & 53.47 & 11 \\
\hline FND & $\begin{array}{l}\text { Representation } \\
\text { of Numeric } \\
\text { and Character } \\
\text { Data }\end{array}$ & 2 & 2 & 0.99 & 54.46 & 18 \\
\hline MATH & $\begin{array}{l}\text { Discrete Math- } \\
\text { ematics }\end{array}$ & 2 & 2 & 0.99 & 55.45 & 18 \\
\hline MATH & $\begin{array}{l}\text { Probability } \\
\text { Theory and } \\
\text { Statistics }\end{array}$ & 2 & 2 & 0.99 & 56.44 & 18 \\
\hline MATH & Optimization & 2 & 2 & 0.99 & 57.43 & 18 \\
\hline ARCH & $\begin{array}{l}\text { General Pur- } \\
\text { pose Processor }\end{array}$ & 2 & 2 & 0.99 & 58.42 & 18 \\
\hline $\mathrm{ARCH}$ & $\begin{array}{l}\text { Memory Ar- } \\
\text { chitecture, } \\
\text { Memory } \\
\text { Device }\end{array}$ & 2 & 2 & 0.99 & 59.41 & 18 \\
\hline $\mathrm{ARCH}$ & $\begin{array}{l}\text { Hardware } \\
\text { Interface }\end{array}$ & 2 & & 0.99 & 60.40 & 18 \\
\hline $\mathrm{ARCH}$ & $\begin{array}{l}\text { Instrumental } \\
\text { Engineering }\end{array}$ & 2 & & 0.99 & 61.39 & 18 \\
\hline $\mathrm{ARCH}$ & $\begin{array}{ll}\begin{array}{l}\text { Control Engi- } \\
\text { neering }\end{array} & \\
\end{array}$ & 2 & & 0.99 & 62.38 & 18 \\
\hline $\mathrm{ARCH}$ & $\begin{array}{l}\text { High Per- } \\
\text { formance } \\
\text { Computing }\end{array}$ & 2 & 2 & 0.99 & 63.37 & 18 \\
\hline OS & Basic Concepts & 2 & 2 & 0.99 & 64.36 & 18 \\
\hline OS & $\begin{array}{l}\text { Organization } \\
\text { and Evaluation } \\
\text { of Operating } \\
\text { System }\end{array}$ & 2 & 2 & 0.99 & 65.35 & 18 \\
\hline OS & $\begin{array}{l}\text { Implementa- } \\
\text { tion of Operat- } \\
\text { ing System }\end{array}$ & 2 & 2 & 0.99 & 66.34 & 18 \\
\hline
\end{tabular}

\begin{tabular}{|c|c|c|c|c|c|c|}
\hline \multirow[t]{2}{*}{ Field } & \multirow[t]{2}{*}{ Area } & \multicolumn{2}{|c|}{ Req.Level } & \multicolumn{3}{|c|}{ Importance Level } \\
\hline & & KLG & SKL & $\%$ & Acc $\%$ & Rank \\
\hline $\begin{array}{l}\text { MM- } \\
\text { DP }\end{array}$ & $\begin{array}{l}\text { Application } \\
\text { of Multi- } \\
\text { media Data } \\
\text { Processing }\end{array}$ & 2 & & 0.99 & 67.33 & 18 \\
\hline HUI & $\begin{array}{l}\text { Interaction and } \\
\text { HMI }\end{array}$ & 2 & 2 & 0.99 & 68.32 & 18 \\
\hline $\begin{array}{l}\text { Usa- } \\
\text { bility }\end{array}$ & $\begin{array}{l}\text { Usability } \\
\text { Design }\end{array}$ & 2 & 2 & 0.99 & 69.31 & 18 \\
\hline $\begin{array}{l}\text { Tele- } \\
\text { comm }\end{array}$ & $\begin{array}{l}\text { Communica- } \\
\text { tion Technol- } \\
\text { ogy }\end{array}$ & 2 & 2 & 0.99 & 70.30 & 18 \\
\hline $\begin{array}{l}\text { Tele- } \\
\text { comm }\end{array}$ & $\begin{array}{l}\text { Law, Social } \\
\text { System, Stan- } \\
\text { dardization }\end{array}$ & 2 & & 0.99 & 71.29 & 18 \\
\hline NET & $\begin{array}{l}\text { Implementa- } \\
\text { tion of Com- } \\
\text { puter Network }\end{array}$ & 2 & 2 & 0.99 & 72.28 & 18 \\
\hline NET & $\begin{array}{l}\text { Network Man- } \\
\text { agement }\end{array}$ & 2 & & 0.99 & 73.27 & 18 \\
\hline NET & $\begin{array}{l}\text { Distributed } \\
\text { System }\end{array}$ & 2 & 2 & 0.99 & 74.26 & 18 \\
\hline WEB & Web Software & 2 & 2 & 0.99 & 75.25 & 18 \\
\hline $\begin{array}{l}\text { Secu- } \\
\text { rity }\end{array}$ & $\begin{array}{l}\text { Network Secu- } \\
\text { rity }\end{array}$ & 2 & 2 & 0.99 & 76.24 & 18 \\
\hline $\begin{array}{l}\text { Secu- } \\
\text { rity }\end{array}$ & $\begin{array}{l}\text { Authentifica- } \\
\text { tion }\end{array}$ & 2 & 2 & 0.99 & 77.23 & 18 \\
\hline DB & $\begin{array}{l}\text { Database Sys- } \\
\text { tem Concepts }\end{array}$ & 2 & 2 & 0.99 & 78.22 & 18 \\
\hline DB & $\begin{array}{l}\text { Database Lan- } \\
\text { guage }\end{array}$ & 2 & 2 & 0.99 & 79.21 & 18 \\
\hline DB & DBMS & 2 & 2 & 0.99 & 80.20 & 18 \\
\hline$\overline{\mathrm{DB}}$ & $\begin{array}{l}\text { Transaction } \\
\text { Management }\end{array}$ & 2 & 2 & 0.99 & 81.19 & 18 \\
\hline DB & $\begin{array}{l}\text { Logical } \\
\text { Database } \\
\text { Design }\end{array}$ & 2 & 2 & 0.99 & 82.18 & 18 \\
\hline DB & $\begin{array}{l}\text { Physical } \\
\text { Database } \\
\text { Design }\end{array}$ & 2 & 2 & 0.99 & 83.17 & 18 \\
\hline$\overline{\mathrm{DB}}$ & $\begin{array}{l}\text { Specific } \\
\text { DBMS }\end{array}$ & 2 & & 0.99 & 84.16 & 18 \\
\hline ALGO & Data Structure & 2 & 2 & 0.99 & 85.15 & 18 \\
\hline ALGO & $\begin{array}{l}\text { Basic } \text { Algo- } \\
\text { rithms }\end{array}$ & 2 & 2 & 0.99 & 86.14 & 18 \\
\hline ALGO & $\begin{array}{l}\text { Algorithm De- } \\
\text { sign }\end{array}$ & 2 & 2 & 0.99 & 87.13 & 18 \\
\hline PRG & $\begin{array}{l}\text { Foundation of } \\
\text { Programming } \\
\text { Language }\end{array}$ & 2 & 2 & 0.99 & 88.12 & 18 \\
\hline PRG & $\begin{array}{l}\text { Specific Pro- } \\
\text { gramming } \\
\text { Language }\end{array}$ & 2 & 2 & 0.99 & 89.11 & 18 \\
\hline SWE & $\begin{array}{l}\text { Software } \\
\text { Reuse }\end{array}$ & 2 & 2 & 0.99 & 90.10 & 18 \\
\hline PM & $\begin{array}{l}\text { Fundamental } \\
\text { Concepts }\end{array}$ & 2 & & 0.99 & 91.09 & 18 \\
\hline PM & $\begin{array}{l}\text { Time Manage- } \\
\text { ment }\end{array}$ & 2 & 2 & 0.99 & 92.08 & 18 \\
\hline PM & $\begin{array}{l}\text { Cost Manage- } \\
\text { ment }\end{array}$ & 2 & 2 & 0.99 & 93.07 & 18 \\
\hline PM & $\begin{array}{l}\text { Quality Man- } \\
\text { agement }\end{array}$ & 2 & 2 & 0.99 & 94.06 & 18 \\
\hline OPR & Maintenance & 2 & 2 & 0.99 & 95.05 & 18 \\
\hline $\begin{array}{l}\text { Busi- } \\
\text { ness }\end{array}$ & Law and Ethics & 2 & & 0.99 & 96.04 & 18 \\
\hline $\begin{array}{l}\text { Busi- } \\
\text { ness }\end{array}$ & Accounting & 2 & 2 & 0.99 & 97.03 & 18 \\
\hline
\end{tabular}




\begin{tabular}{|l|l|c|c|c|c|c|}
\hline \hline \multirow{2}{*}{ Field } & Area & \multicolumn{2}{|c|}{ Req.Level } & \multicolumn{3}{|c|}{ Importance Level } \\
\cline { 3 - 7 } & & KLG & SKL & $\%$ & Acc \% & Rank \\
\hline $\begin{array}{l}\text { Busi- } \\
\text { ness }\end{array}$ & Marketing & 2 & & 0.99 & 98.02 & 18 \\
\hline $\begin{array}{l}\text { Busi- } \\
\text { ness }\end{array}$ & $\begin{array}{l}\text { Decision Mak- } \\
\text { ing }\end{array}$ & 2 & 2 & 0.99 & 99.01 & 18 \\
\hline SOC & $\begin{array}{l}\text { Information } \\
\text { Ethics }\end{array}$ & 2 & & 0.99 & 100.00 & 18 \\
\hline
\end{tabular}

A.3.3 Applied Information Technology Engineer Examination (AP)

\begin{tabular}{|c|c|c|c|c|c|c|}
\hline \multirow[t]{2}{*}{ Field } & \multirow[t]{2}{*}{ Area } & \multicolumn{2}{|c|}{ Req.Level } & \multicolumn{3}{|c|}{ Importance Level } \\
\hline & & KLG & SKL & $\%$ & Acc $\%$ & Rank \\
\hline $\begin{array}{l}\text { Busi- } \\
\text { ness }\end{array}$ & Operation & 3 & 3 & 5.88 & 5.88 & 1 \\
\hline OPR & Operation & 4 & 4 & 4.90 & 10.78 & 2 \\
\hline $\begin{array}{l}\text { Busi- } \\
\text { ness }\end{array}$ & $\begin{array}{l}\text { Business Strat- } \\
\text { egy and Orga- } \\
\text { nization }\end{array}$ & 3 & 3 & 4.90 & 15.69 & 2 \\
\hline $\begin{array}{l}\text { Secu- } \\
\text { rity }\end{array}$ & $\begin{array}{l}\text { Security Man- } \\
\text { agement }\end{array}$ & 4 & 4 & 3.92 & 19.61 & 4 \\
\hline PM & $\begin{array}{l}\text { Management } \\
\text { on Others }\end{array}$ & 3 & 3 & 3.92 & 23.53 & 4 \\
\hline OPR & Planning & 4 & 4 & 3.92 & 27.45 & 4 \\
\hline SWE & $\begin{array}{l}\text { Requirement } \\
\text { Analysis }\end{array}$ & 4 & 4 & 2.94 & 30.39 & 7 \\
\hline SWE & $\begin{array}{l}\text { Validation and } \\
\text { Testing }\end{array}$ & 4 & 4 & 2.94 & 33.33 & 7 \\
\hline OPR & Evaluation & 4 & 4 & 2.94 & 36.27 & 7 \\
\hline OPR & $\begin{array}{l}\text { Specific Infor- } \\
\text { mation System }\end{array}$ & 3 & 3 & 2.94 & 39.22 & 7 \\
\hline $\mathrm{ARCH}$ & $\begin{array}{l}\text { Memory Ar- } \\
\text { chitecture, } \\
\text { Memory } \\
\text { Device }\end{array}$ & 4 & 4 & 1.96 & 41.18 & 11 \\
\hline $\mathrm{ARCH}$ & $\begin{array}{l}\text { Embedded } \\
\text { Systems }\end{array}$ & 3 & 3 & 1.96 & 43.14 & 11 \\
\hline HW & $\mathrm{I} / \mathrm{O}$ & 4 & 4 & 1.96 & 45.10 & 11 \\
\hline PRG & $\begin{array}{l}\text { Foundation of } \\
\text { Programming }\end{array}$ & 4 & 4 & 1.96 & 47.06 & 11 \\
\hline SWE & $\begin{array}{l}\text { Software Pro- } \\
\text { cess }\end{array}$ & 4 & 4 & 1.96 & 49.02 & 11 \\
\hline SWE & $\begin{array}{l}\text { Software De- } \\
\text { velopment } \\
\text { Environment }\end{array}$ & 4 & 4 & 1.96 & 50.98 & 11 \\
\hline PM & $\begin{array}{l}\text { Acquisition } \\
\text { Management }\end{array}$ & 3 & 3 & 1.96 & 52.94 & 11 \\
\hline SOC & $\begin{array}{l}\text { Intellectual } \\
\text { Property }\end{array}$ & 4 & 4 & 1.96 & 54.90 & 11 \\
\hline FND & $\begin{array}{l}\text { Representation } \\
\text { of Numeric } \\
\text { and Character } \\
\text { Data }\end{array}$ & 4 & 4 & 0.98 & 55.88 & 19 \\
\hline MATH & $\begin{array}{l}\text { Discrete Math- } \\
\text { ematics }\end{array}$ & 4 & 4 & 0.98 & 56.86 & 19 \\
\hline MATH & Optimization & 4 & 4 & 0.98 & 57.84 & 19 \\
\hline $\mathrm{ARCH}$ & $\begin{array}{l}\text { General Pur- } \\
\text { pose Processor }\end{array}$ & 4 & 4 & 0.98 & 58.82 & 19 \\
\hline $\mathrm{ARCH}$ & $\begin{array}{l}\text { Hardware } \\
\text { Interface }\end{array}$ & 4 & 4 & 0.98 & 59.80 & 19 \\
\hline $\mathrm{ARCH}$ & $\begin{array}{l}\text { Control Engi- } \\
\text { neering }\end{array}$ & 4 & 4 & 0.98 & 60.78 & 19 \\
\hline $\mathrm{ARCH}$ & $\begin{array}{l}\text { High Per- } \\
\text { formance } \\
\text { Computing }\end{array}$ & 4 & 4 & 0.98 & 61.76 & 19 \\
\hline OS & Basic Concepts & 4 & 4 & 0.98 & 62.75 & 19 \\
\hline
\end{tabular}

\begin{tabular}{|c|c|c|c|c|c|c|}
\hline \multirow[t]{2}{*}{ Field } & \multirow[t]{2}{*}{ Area } & \multicolumn{2}{|c|}{ Req.Level } & \multicolumn{3}{|c|}{ Importance Level } \\
\hline & & KLG & SKL & $\%$ & Acc $\%$ & Rank \\
\hline OS & $\begin{array}{l}\text { Organization } \\
\text { and Evaluation } \\
\text { of Operating } \\
\text { System }\end{array}$ & 4 & 4 & 0.98 & 63.73 & 19 \\
\hline OS & $\begin{array}{l}\text { Implementa- } \\
\text { tion of Operat- } \\
\text { ing System }\end{array}$ & 4 & 4 & 0.98 & 64.71 & 19 \\
\hline $\begin{array}{l}\text { MM- } \\
\text { DP }\end{array}$ & $\begin{array}{l}\text { Application } \\
\text { of Multi- } \\
\text { media Data } \\
\text { Processing }\end{array}$ & 4 & 4 & 0.98 & 65.69 & 19 \\
\hline HUI & $\begin{array}{l}\text { Interaction and } \\
\text { HMI }\end{array}$ & 4 & 4 & 0.98 & 66.67 & 19 \\
\hline $\begin{array}{l}\text { Usa- } \\
\text { bility }\end{array}$ & $\begin{array}{l}\text { Usability } \\
\text { Design }\end{array}$ & 4 & 4 & 0.98 & 67.65 & 19 \\
\hline $\begin{array}{l}\text { Usa- } \\
\text { bility }\end{array}$ & $\begin{array}{l}\text { Usability Eval- } \\
\text { uation }\end{array}$ & 4 & 4 & 0.98 & 68.63 & 19 \\
\hline $\begin{array}{l}\text { Tele- } \\
\text { comm }\end{array}$ & $\begin{array}{l}\text { Communica- } \\
\text { tion Technol- } \\
\text { ogy }\end{array}$ & 4 & 4 & 0.98 & 69.61 & 19 \\
\hline $\begin{array}{l}\text { Tele- } \\
\text { comm }\end{array}$ & $\begin{array}{l}\text { Law, Social } \\
\text { System, Stan- } \\
\text { dardization }\end{array}$ & 3 & 3 & 0.98 & 70.59 & 19 \\
\hline NET & $\begin{array}{l}\text { Implementa- } \\
\text { tion of Com- } \\
\text { puter Network }\end{array}$ & 4 & 4 & 0.98 & 71.57 & 19 \\
\hline NET & $\begin{array}{l}\text { Network Man- } \\
\text { agement }\end{array}$ & 4 & 4 & 0.98 & 72.55 & 19 \\
\hline NET & $\begin{array}{l}\text { Distributed } \\
\text { System }\end{array}$ & 4 & 4 & 0.98 & 73.53 & 19 \\
\hline WEB & Web Software & 4 & 4 & 0.98 & 74.51 & 19 \\
\hline $\begin{array}{l}\text { Secu- } \\
\text { rity }\end{array}$ & $\begin{array}{l}\text { Network Secu- } \\
\text { rity }\end{array}$ & 4 & 4 & 0.98 & 75.49 & 19 \\
\hline $\begin{array}{l}\text { Secu- } \\
\text { rity }\end{array}$ & $\begin{array}{l}\text { Authentifica- } \\
\text { tion }\end{array}$ & 4 & 4 & 0.98 & 76.47 & 19 \\
\hline DB & $\begin{array}{l}\text { Database Sys- } \\
\text { tem Concepts }\end{array}$ & 4 & 4 & 0.98 & 77.45 & 19 \\
\hline DB & $\begin{array}{l}\text { Database Lan- } \\
\text { guage }\end{array}$ & 4 & 4 & 0.98 & 78.43 & 19 \\
\hline DB & DBMS & 4 & 4 & 0.98 & 79.41 & 19 \\
\hline DB & $\begin{array}{l}\text { Transaction } \\
\text { Management }\end{array}$ & 4 & 4 & 0.98 & 80.39 & 19 \\
\hline DB & $\begin{array}{l}\text { Logical } \\
\text { Database } \\
\text { Design }\end{array}$ & 4 & 4 & 0.98 & 81.37 & 19 \\
\hline DB & $\begin{array}{l}\text { Physical } \\
\text { Database } \\
\text { Design }\end{array}$ & 4 & 4 & 0.98 & 82.35 & 19 \\
\hline$\overline{\mathrm{DB}}$ & $\begin{array}{l}\text { System Devel- } \\
\text { opment, Man- } \\
\text { agement, Op- } \\
\text { eration }\end{array}$ & 4 & 4 & 0.98 & 83.33 & 19 \\
\hline DB & $\begin{array}{l}\text { Specific } \\
\text { DBMS }\end{array}$ & 4 & 4 & 0.98 & 84.31 & 19 \\
\hline ALGO & Data Structure & 4 & 4 & 0.98 & 85.29 & 19 \\
\hline ALGO & $\begin{array}{ll}\text { Basic } & \text { Algo- } \\
\text { rithms }\end{array}$ & 4 & 4 & 0.98 & 86.27 & 19 \\
\hline ALGO & $\begin{array}{l}\text { Algorithm De- } \\
\text { sign }\end{array}$ & 4 & 4 & 0.98 & 87.25 & 19 \\
\hline PRG & $\begin{array}{l}\text { Specific Pro- } \\
\text { gramming } \\
\text { Language }\end{array}$ & 4 & 4 & 0.98 & 88.24 & 19 \\
\hline SWE & $\begin{array}{l}\text { Metrics and } \\
\text { Measurement }\end{array}$ & 3 & 3 & 0.98 & 89.22 & 19 \\
\hline SWE & $\begin{array}{l}\text { Software } \\
\text { Reuse }\end{array}$ & 4 & 4 & 0.98 & 90.20 & 19 \\
\hline PM & $\begin{array}{l}\text { Fundamental } \\
\text { Concepts }\end{array}$ & 4 & 4 & 0.98 & 91.18 & 19 \\
\hline
\end{tabular}




\begin{tabular}{|l|l|c|c|c|c|c|}
\hline \hline \multirow{2}{*}{ Field } & Area & \multicolumn{2}{|c|}{ Req.Level } & \multicolumn{3}{|c|}{ Importance Level } \\
\cline { 2 - 7 } & & KLG & SKL & $\%$ & Acc $\%$ & Rank \\
\hline PM & $\begin{array}{l}\text { Time Manage- } \\
\text { ment }\end{array}$ & 3 & 3 & 0.98 & 92.16 & 19 \\
\hline PM & $\begin{array}{l}\text { Cost Manage- } \\
\text { ment }\end{array}$ & 3 & 3 & 0.98 & 93.14 & 19 \\
\hline PM & $\begin{array}{l}\text { Quality Man- } \\
\text { agement }\end{array}$ & 3 & 3 & 0.98 & 94.12 & 19 \\
\hline OPR & Maintenance & 4 & 4 & 0.98 & 95.10 & 19 \\
\hline $\begin{array}{l}\text { Busi- } \\
\text { ness }\end{array}$ & $\begin{array}{l}\text { Law and Ethics } \\
\text { Busi- } \\
\text { ness }\end{array}$ & 3 & 3 & 0.98 & 96.08 & 19 \\
\hline $\begin{array}{l}\text { Busi- } \\
\text { ness }\end{array}$ & Marketing & 3 & 3 & 0.98 & 98.04 & 19 \\
\hline $\begin{array}{l}\text { Busi- } \\
\text { ness }\end{array}$ & $\begin{array}{l}\text { Decision Mak- } \\
\text { ing }\end{array}$ & 4 & 4 & 0.98 & 99.02 & 19 \\
\hline $\begin{array}{l}\text { SOC } \\
\text { Information }\end{array}$ & 3 & 3 & 0.98 & 100.00 & 19 \\
\hline
\end{tabular}

\section{A.3.4 Information Security Engineer Examination (SC)}

\begin{tabular}{|l|l|c|c|c|c|c|}
\hline \hline \multirow{2}{*}{ Field } & \multirow{2}{*}{ Area } & \multicolumn{2}{|c|}{ Req.Level } & \multicolumn{3}{|c|}{ Importance Level } \\
\cline { 3 - 7 } & & KLG & SKL & $\%$ & Acc \% & Rank \\
\hline $\begin{array}{l}\text { Secu- } \\
\text { rity }\end{array}$ & $\begin{array}{l}\text { Security Man- } \\
\text { agement }\end{array}$ & 4 & 5 & 17.65 & 17.65 & 1 \\
\hline OPR & Evaluation & 4 & 5 & 17.65 & 35.29 & 1 \\
\hline SWE & $\begin{array}{l}\text { Validation and } \\
\text { Testing }\end{array}$ & 4 & 5 & 14.71 & 50.00 & 3 \\
\hline OPR & Planning & 4 & 5 & 14.71 & 64.71 & 3 \\
\hline $\begin{array}{l}\text { Secu- } \\
\text { rity }\end{array}$ & $\begin{array}{l}\text { Security and } \\
\text { Society }\end{array}$ & 4 & 5 & 8.82 & 73.53 & 5 \\
\hline $\begin{array}{l}\text { COM- } \\
\text { M }\end{array}$ & $\begin{array}{l}\text { Reading, Writ- } \\
\text { ing, Presenta- } \\
\text { tion }\end{array}$ & 4 & 5 & 8.82 & 82.35 & 5 \\
\hline SWE & $\begin{array}{l}\text { Requirement } \\
\text { Analysis }\end{array}$ & 4 & 5 & 5.88 & 88.24 & 7 \\
\hline SWE & $\begin{array}{l}\text { Software } \\
\text { Architecture }\end{array}$ & 4 & 5 & 5.88 & 94.12 & 7 \\
\hline SWE & $\begin{array}{l}\text { Structured } \\
\text { Analysis and } \\
\text { Design }\end{array}$ & 4 & 5 & 2.94 & 97.06 & 9 \\
\hline SWE & $\begin{array}{l}\text { Software Pro- } \\
\text { cess }\end{array}$ & 4 & 5 & 2.94 & 100.00 & 9 \\
\hline
\end{tabular}

\section{A.3.5 Network Specialist Examination (NW)}

\begin{tabular}{|l|l|c|c|c|c|c|}
\hline \hline \multirow{2}{*}{ Field } & Area & \multicolumn{2}{|c|}{ Req.Level } & \multicolumn{3}{|c|}{ Importance Level } \\
\cline { 3 - 7 } & & KLG & SKL & $\%$ & Acc \% & Rank \\
\hline $\begin{array}{l}\text { Tele- } \\
\text { comm }\end{array}$ & $\begin{array}{l}\text { Development, } \\
\text { Management } \\
\text { and Operation }\end{array}$ & 4 & 5 & 16.67 & 16.67 & 1 \\
\hline SWE & $\begin{array}{l}\text { Requirement } \\
\text { Analysis }\end{array}$ & 4 & 5 & 13.33 & 30.00 & 2 \\
\hline OPR & Evolution & 4 & 5 & 13.33 & 43.33 & 2 \\
\hline NET & $\begin{array}{l}\text { Network Man- } \\
\text { agement }\end{array}$ & 4 & 5 & 10.00 & 53.33 & 4 \\
\hline SWE & $\begin{array}{l}\text { Validation and } \\
\text { Testing }\end{array}$ & 4 & 5 & 10.00 & 63.33 & 4 \\
\hline OPR & Planning & 4 & 5 & 10.00 & 73.33 & 4 \\
\hline OPR & Evaluation & 4 & 5 & 10.00 & 83.33 & 4 \\
\hline $\begin{array}{l}\text { Secu- } \\
\text { rity }\end{array}$ & $\begin{array}{l}\text { Security Man- } \\
\text { agement }\end{array}$ & 4 & 5 & 3.33 & 86.67 & 8 \\
\hline SWE & $\begin{array}{l}\text { Software } \\
\text { Architecture }\end{array}$ & 4 & 5 & 3.33 & 90.00 & 8 \\
\hline PM & $\begin{array}{l}\text { Fundamental } \\
\text { Concepts }\end{array}$ & 4 & 5 & 3.33 & 93.33 & 8 \\
\hline OPR & Maintenance & 4 & 5 & 3.33 & 96.67 & 8 \\
\hline
\end{tabular}

\begin{tabular}{|l|l|c|c|c|c|c|}
\hline \hline Field & Area & \multicolumn{2}{|c|}{ Req.Level } & \multicolumn{3}{|c|}{ Importance Level } \\
\cline { 3 - 7 } & & KLG & SKL & $\%$ & Acc \% & Rank \\
\hline $\begin{array}{l}\text { Busi- } \\
\text { ness }\end{array}$ & $\begin{array}{l}\text { Decision Mak- } \\
\text { ing }\end{array}$ & 4 & 5 & 3.33 & 100.00 & 8 \\
\hline
\end{tabular}

\section{A.3.6 Project Manager Examination (PM)}

\begin{tabular}{|l|l|c|c|c|c|c|}
\hline \hline \multirow{2}{*}{ Field } & \multirow{2}{*}{ Area } & \multicolumn{2}{|c|}{ Req.Level } & \multicolumn{3}{|c|}{ Importance Level } \\
\cline { 3 - 7 } & & KLG & SKL & $\%$ & Acc $\%$ & Rank \\
\hline PM & $\begin{array}{l}\text { Management } \\
\text { on Others }\end{array}$ & 4 & 5 & 25.00 & 25.00 & 1 \\
\hline PM & $\begin{array}{l}\text { Time Manage- } \\
\text { ment }\end{array}$ & 4 & 5 & 19.44 & 44.44 & 2 \\
\hline PM & $\begin{array}{l}\text { Fundamental } \\
\text { Concepts }\end{array}$ & 4 & 5 & 11.11 & 55.56 & 3 \\
\hline PM & $\begin{array}{l}\text { Cost Manage- } \\
\text { ment }\end{array}$ & 4 & 5 & 11.11 & 66.67 & 3 \\
\hline PM & $\begin{array}{l}\text { Quality Man- } \\
\text { agement }\end{array}$ & 4 & 5 & 5.56 & 72.22 & 5 \\
\hline PM & $\begin{array}{l}\text { Acquisition } \\
\text { Management }\end{array}$ & 4 & 5 & 5.56 & 77.78 & 5 \\
\hline OPR & Planning & 4 & 5 & 5.56 & 83.33 & 5 \\
\hline OPR & Evaluation & 4 & 5 & 5.56 & 88.89 & 5 \\
\hline $\begin{array}{l}\text { COM- } \\
\text { M }\end{array}$ & $\begin{array}{l}\text { Reading, Writ- } \\
\text { ing, Presenta- } \\
\text { tion }\end{array}$ & 4 & 5 & 5.56 & 94.44 & 5 \\
\hline $\begin{array}{l}\text { COM- } \\
\text { M }\end{array}$ & \begin{tabular}{l} 
Practical Skill \\
\hline
\end{tabular} & 4 & 5 & 5.56 & 100.00 & 5 \\
\hline
\end{tabular}

\section{A.3.7 System Architect Examination (SA)}

\begin{tabular}{|l|l|c|c|c|c|c|}
\hline \hline \multirow{2}{*}{ Field } & Area & \multicolumn{2}{|c|}{ Req.Level } & \multicolumn{3}{|c|}{ Importance Level } \\
\cline { 2 - 6 } & & KLG & SKL & $\%$ & Acc \% & Rank \\
\hline SWE & $\begin{array}{l}\text { Requirement } \\
\text { Analysis }\end{array}$ & 4 & 5 & 15.93 & 15.93 & 1 \\
\hline SWE & $\begin{array}{l}\text { Validation and } \\
\text { Testing }\end{array}$ & 4 & 5 & 14.16 & 30.09 & 2 \\
\hline OPR & Planning & 4 & 5 & 14.16 & 44.25 & 2 \\
\hline OPR & Operation & 4 & 5 & 10.62 & 54.87 & 4 \\
\hline SWE & $\begin{array}{l}\text { Object Ori- } \\
\text { ented Analysis } \\
\text { and Design }\end{array}$ & 4 & 5 & 7.08 & 61.95 & 5 \\
\hline SWE & $\begin{array}{l}\text { Structured } \\
\text { Analysis and } \\
\text { Design }\end{array}$ & 4 & 5 & 6.19 & 68.14 & 6 \\
\hline OPR & Evaluation & 4 & 5 & 6.19 & 74.34 & 6 \\
\hline OPR & Maintenance & 4 & 5 & 4.42 & 78.76 & 8 \\
\hline SWE & $\begin{array}{l}\text { Software Pro- } \\
\text { cess }\end{array}$ & 4 & 5 & 2.65 & 81.42 & 9 \\
\hline $\begin{array}{l}\text { Busi- } \\
\text { ness }\end{array}$ & $\begin{array}{l}\text { Decision Mak- } \\
\text { ing }\end{array}$ & 4 & 5 & 2.65 & 84.07 & 9 \\
\hline $\begin{array}{l}\text { COM- } \\
\text { M }\end{array}$ & $\begin{array}{l}\text { Reading, Writ- } \\
\text { ing, Presenta- } \\
\text { tion }\end{array}$ & 4 & 5 & 2.65 & 86.73 & 9 \\
\hline SWE & Data Modeling & 4 & 5 & 1.77 & 88.50 & 12 \\
\hline SWE & $\begin{array}{l}\text { Software } \\
\text { Architecture }\end{array}$ & 4 & 5 & 1.77 & 90.27 & 12 \\
\hline SWE & $\begin{array}{l}\text { Software } \\
\text { Reuse }\end{array}$ & 4 & 5 & 1.77 & 92.04 & 12 \\
\hline OPM & $\begin{array}{l}\text { Fundamental } \\
\text { Concepts }\end{array}$ & 4 & 5 & 1.77 & 93.81 & 12 \\
\hline DB & Evolution & 4 & 5 & 1.77 & 95.58 & 12 \\
\hline Specific OS & 4 & 5 & 0.88 & 96.46 & 17 \\
\hline
\end{tabular}




\begin{tabular}{|l|l|c|c|c|c|c|}
\hline \hline Field & Area & \multicolumn{2}{|c|}{ Req.Level } & \multicolumn{3}{|c|}{ Importance Level } \\
\cline { 3 - 7 } & & KLG & SKL & $\%$ & Acc \% & Rank \\
\hline SWE & $\begin{array}{l}\text { Software De- } \\
\text { velopment } \\
\text { Environment }\end{array}$ & 4 & 5 & 0.88 & 98.23 & 17 \\
\hline PM & $\begin{array}{l}\text { Cost Manage- } \\
\text { ment }\end{array}$ & 4 & 5 & 0.88 & 99.12 & 17 \\
\hline PM & $\begin{array}{l}\text { Acquisition } \\
\text { Management }\end{array}$ & 4 & 5 & 0.88 & 100.00 & 17 \\
\hline
\end{tabular}

A.3.8 Database Specialist Examination (DB)

\begin{tabular}{|l|l|c|c|c|c|c|}
\hline \hline Field & Area & \multicolumn{2}{|c|}{ Req.Level } & \multicolumn{3}{|c|}{ Importance Level } \\
\cline { 3 - 7 } & & KLG & SKL & $\%$ & Acc \% & Rank \\
\hline DB & $\begin{array}{l}\text { System Devel- } \\
\text { opment, Man- } \\
\text { agement, Op- } \\
\text { eration }\end{array}$ & 4 & 5 & 55.56 & 55.56 & 1 \\
\hline DB & $\begin{array}{l}\text { Logical } \\
\text { Database } \\
\text { Design }\end{array}$ & 4 & 5 & 22.22 & 77.78 & 2 \\
\hline SWE & $\begin{array}{l}\text { Requirement } \\
\text { Analysis }\end{array}$ & 4 & 5 & 16.67 & 94.44 & 3 \\
\hline DB & $\begin{array}{l}\text { Physical } \\
\text { Database } \\
\text { Design }\end{array}$ & 4 & 5 & 5.56 & 100.00 & 4 \\
\hline
\end{tabular}

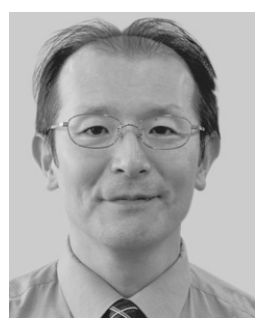

Tetsuro Kakeshita received his Ph.D. degree in Computer Science from Kyushu University in 1989. Currently he is an associate professor at Saga University. His major research interests include complexity analysis of database and software system, and quantitative analysis of ICT education. He received an excellent educator award from IPSJ in 2013 and is a member of the IPSJ, IEICE, IEEE-CS and ACM.

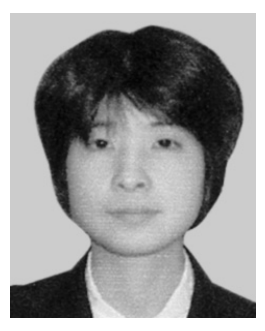

Mika Ohtsuki received her Ph.D. degree in Computer Science from Kyushu University in 1999. Currently she is a lecturer at Saga University. Her major research interests are software engineering, object oriented software development and online education. She is a member of the IPSJ and Japan Society for Graphic Science. 